\title{
Cell-Permeable Peptide Targeting the Nrf2-Keap1 Interaction: A Potential Novel Therapy for Global Cerebral Ischemia
}

\author{
Jingyi Tu, ${ }^{1}$ Xi Zhang, ${ }^{1}$ Ying Zhu, ${ }^{1}$ Yongxin Dai, ${ }^{1}$ Ning Li, ${ }^{1}$ Fang Yang, ${ }^{1}$ Quanguang Zhang, ${ }^{2}$ Darrell W. Brann, ${ }^{2,3}$ \\ and $\odot$ Ruimin Wang ${ }^{1}$ \\ ${ }^{1}$ Neurobiology Institute of Medical Research Center, International Science \& Technology Cooperation Base of Geriatric Medicine, North China University of \\ Science and Technology, Tangshan, Hebei 063000, China, ${ }^{2}$ Department of Neuroscience and Regenerative Medicine, Medical College of Georgia, Georgia \\ Regents University, Augusta, Georgia 30912, and ${ }^{3}$ Charlie Norwood Veterans Affairs Medical Center, Augusta, Georgia 30904
}

The current study examined efficacy of a small Tat (trans-activator of transcription)-conjugated peptide activator of the Nrf2 (nuclear factor-E2-related factor-2) antioxidant/cell-defense pathway as a potential injury-specific, novel neuroprotectant against global cerebral ischemia (GCI). A competitive peptide, DEETGE-CAL-Tat, was designed to facilitate Nrf2 activation by disrupting interaction of Nrf2 with Keap1 (kelch-like ECH-associated protein 1), a protein that sequesters Nrf2 in the cytoplasm and thereby inactivates it. The DEETGECAL-Tat peptide contained the critical sequence DEETGE for the Nrf2-Keap1 interaction, the cell transduction domain of the HIV-Tat protein, and the cleavage sequence of calpain, which is sensitive to $\mathrm{Ca}^{2+}$ increase and allows injury-specific activation of Nrf2. Using an animal model of GCI, we demonstrated that pretreatment with the DEETGE-CAL-Tat peptide markedly decreased Nrf2 interaction with Keap1 in the rat hippocampal CA1 region after GCI, and enhanced Nrf2 nuclear translocation and DNA binding. The DEETGE-CAL-Tat peptide also induced Nrf2 antioxidant/cytoprotective target genes, reduced oxidative stress, and induced strong neuroprotection and marked preservation of hippocampal-dependent cognitive function after GCI. These effects were specific as control peptides lacked neuroprotective ability. Intriguingly, the DEETGE-CAL-Tat peptide effects were also injury specific, as it had no effect upon neuronal survival or cognitive performance in sham nonischemic animals. Of significant interest, peripheral, postischemia administration of the DEETGE-CAL-Tat peptide from days 1-9 after GCI also induced robust neuroprotection and strongly preserved hippocampal-dependent cognitive function. Based on its robust neuroprotective and cognitive-preserving effects, and its unique injury-specific activation properties, the DEETGE-CAL-Tat peptide represents a novel, and potentially promising new therapeutic modality for the treatment of GCI.

Key words: cardiac arrest; cognitive defect; hippocampus CA1 region; neuroprotection; peptide; reactive oxidative species

Significance Statement

The current study demonstrates that DEETGE-CAL-Tat, a novel peptide activator of a key antioxidant gene transcription pathway in the hippocampus after global cerebral ischemia, can exert robust neuroprotection and preservation of cognitive function. A unique feature of the peptide is that its beneficial effects are injury specific. This feature is attractive as it targets drug activation specifically in the site of injury, and likely would lead to a reduction of undesirable side effects if translatable to the clinic. Due to its injury-specific activation, robust neuroprotection, and cognitive-preserving effects, this novel peptide may represent a muchneeded therapeutic advance that could have efficacy in the treatment of global cerebral ischemia.

\section{Introduction}

Cardiac arrest is a leading cause of death and disability in the United States, with 350,000-500,000 cardiac arrests occurring each year in the United States (Roger et al., 2011). A major disability feared by cardiac arrest survivors is cognitive impairment.
A review of several high-quality prospective studies found that cognitive problems occurred in approximately half of the survivors of out-of-hospital cardiac arrest (Roine et al., 1993; Sauvé et al., 1996; Moulaert et al., 2009). Memory problems were the most

This work was supported by the Natural Science Foundation of China $(30970664 ; 31171354)$, Natural Science Foundation of Hebei Province (C2014209277), and the U.S. National Institutes of Neurological Disorders and Stroke, National Institutes of Health (NS050730).

The authors declare no competing financial interests. 
common cognitive impairment after cardiac arrest, followed by impairments in attention and executive functioning (Moulaert et al., 2009). Pathologically, the risk of cognitive impairment is primarily due to global cerebral ischemia (GCI) during cardiac arrest, which can induce delayed neuronal cell death in the hippocampal CA1 region and consequent cognitive decline (Kirino, 1982; Pulsinelli et al., 1982; Brillman, 1993; Swain et al., 1993; Wolman et al., 1999). Experimental GCI induced in animals has proven to be a valuable model for the study of cardiac arrest-induced neuronal cell death and cognitive deficits, as it results in selective and delayed neuronal death of pyramidal neurons in the hippocampal CA1 region, similar to the situation in humans (Kirino, 1982; Pulsinelli et al., 1982; Kirino and Sano, 1984; Chen et al., 1996).

Unfortunately, there are currently no effective drugs available that protect the brain from cardiac arrest-induced neurological impairment. Therapeutic hypothermia is the only strategy to date that has been reported to have neurological benefit in cardiac arrest (Harukuni and Bhardwaj, 2006). However, its beneficial effect is not without controversy, as a recent meta-analysis did not find a strong benefit for hypothermia on survival or neurological outcome (Nielsen et al., 2011; Kim et al., 2012). Thus, new therapeutic strategies for protection of the brain from GCI after cardiac arrest are urgently needed.

In the current study, we tested a novel strategy to enhance a key endogenous defense mechanism present in cells, the Nrf2 (nuclear factor E2-related factor 2) transcriptional system for induction of cytoprotective, antioxidant, and detoxifying genes. $\mathrm{Nrf2}$ is a transcription factor that is normally sequestered in the cytoplasm by binding of the adaptor protein, Keap1 (kelch-like ECH-associated protein-1), which leads to degradation of Nrf2 by the proteosome (McMahon et al., 2004; Villeneuve et al., 2010). Cell stress and/or injury can lead to dissociation of Nrf2 from Keap1, and its translocation to the nucleus, where it induces a battery of cytoprotective, antioxidant, and detoxifying genes that can protect the cell, such as heme oxygenase-1 (HO-1), glutathione-S-transferase, glutathione peroxidase (GPx1), glutathione synthetase, NADPH quinone oxidase-1, epoxide hydrolase, and brain-derived growth factor (Kam et al., 2011; Chen et al., 2012; Guerrero-Beltrán et al., 2012).

Recent work has shown that a DEETGE sequence in Nrf2 is critical for the Nrf2-Keap1 interaction, and that DEETGE-CALTat synthetic peptides that contain the DEETGE sequence, a calpain cleavage site, and a HIV-Tat cell transduction domain, can disrupt the Nrf2-Keap1 interaction and induce Nrf2 genes in vitro and in vivo in animals subjected to traumatic brain injury (Zhao et al., 2011). We thus hypothesized that the DEETGECAL-Tat peptide may have efficacy as a novel therapeutic agent in GCI. We therefore performed preclinical studies using a fourvessel occlusion (4-VO) animal model of GCI to test the hypothesis. The results of our study demonstrated that administration of the DEETGE-CAL-Tat peptide in an animal model of GCI strongly enhanced both nuclear translocation and DNA binding of Nrf2, as well as expression of known Nrf2-regulated target antioxidant/cell-defense proteins in the hippocampal CA1 re-

Correspondence should be addressed to either of the following: Dr. Ruimin Wang, Professor, Neurobiology Institute of Medical Research Center, International Science \& Technology Cooperation Base of Geriatric Medicine, North China University of Science and Technology, $57^{\text {th }}$ Jianshe South Road, Tangshan 063000, China. E-mail: ruimin-wang@163.com; or Dr. Darrell Brann, Regents' Professor and Vice Chair, Department of Neuroscience and Regenerative Medicine, Medical College of Georgia, Georgia Regents University, 1120 Fifteenth Street, Augusta, Georgia 30912. E-mail: dbrann@gru.edu.

DOI:10.1523/JNEUROSCI.1304-15.2015

Copyright $\odot 2015$ the authors $\quad 0270-6474 / 15 / 3514728-13 \$ 15.00 / 0$ gion, and significantly reduced GCI-induced oxidative damage. The study also revealed that intracerebroventricular pretreatment or peripheral post-treatment with the DEETGE-CALTat peptide induced robust neuroprotection in the hippocampal CA1 region and strongly preserved cognitive function after GCI.

\section{Materials and Methods}

Antibodies and reagents. The following antibodies were used: NeuN (Millipore Biotechnology, MAB377), GPx1 (ab22604), $\beta$-actin (sc81178), Nrf2 (sc-722), HO-1 (sc-1797), NAD(P)H dehydrogenase, quinone 1 (NQO1; sc-376023), superoxide dismutase 2 (SOD2; sc-18503), 4-hydroxy-2-nonenal (4HNE; ab46545), 8-hydroxy-2deoxyguanosine (8OHdG; ab62623), Keap1 (\#4617), and Nrf2 (sc30915). Alexa-conjugated secondary antibodies and DAPI were from Invitrogen. Polyvinylidene difluoride (PVDF) membranes with pore size of $0.45 \mu \mathrm{m}$ were from Millipore. BCIP (5-bromo-4-chloro-3indolyl-phosphate) and NBT (nitroblue tetrazolium) were from Promega. Nrf2 transcription factor ELISA kits (catalog \#50296) were from Active Motif. Unless indicated otherwise, all the other chemicals were from Sigma-Aldrich.

Animal model of ischemia and administration of drugs. Adult male Sprague Dawley rats (Beijing HFK Bioscience; weight, 250-300 g) were housed in a temperature-controlled $\left(22-24^{\circ} \mathrm{C}\right)$ room with water and food available ad libitum. All procedures were approved by local legislation for ethics of experiments on animals. GCI was induced by the 4-VO method as described previously (Sun and Gilboe, 1994; Zhang et al., 2011; Wang et al., 2013). Briefly, anesthetization was induced in the rats with chloral hydrate $(20 \% ; 350 \mathrm{mg} / \mathrm{kg}$, i.p. $)$, both vertebral arteries were electrocauterized through the alar foramen of the first cervical vertebra and both common carotid arteries (CAAs) were exposed followed by closing of the incision with a suture. Rats were allowed to recover for $24 \mathrm{~h}$ and fasted overnight. The animals were lightly anesthetized to re-expose and occlude the CAAs for 15 min with aneurysm clips. Rats that lost their righting reflex within $30 \mathrm{~s}$ and whose pupils were dilated and unresponsive to light during ischemia were selected for the experiments. Resumption of carotid artery blood flow was verified visually by releasing the clips. Rectal temperature was maintained at $36.5-37.5^{\circ} \mathrm{C}$ during surgery with a feedback-regulated heating pad. For sham-operated rats, the surgeries were performed exactly as for ischemic animals except that the CAAs were not clamped.

Administrations of DEETGE-CAL-Tat peptide and control peptide. The following peptide was synthesized by SBS Genentech. The DEETGECAL-Tat peptide (NH2-RKKRRQRRR-PLFAER-LDEETGEFLP-CONH2) was designed according to Zhao et al. (2011) with a minor difference in the N-terminal. Rather than amino acids $47-57$ of the cell transduction domain of the HIV-Tat, we used amino acids 49-57 (RKKRRQRRR), which have been identified as the minimal protein transduction domain of the HIV-Tat (Wender et al., 2000; Beerens et al., 2003). The other key structural motifs of the DEETGE-CAL-Tat peptide included (1) the critical sequence DEETGE for the Nrf2-Keap1 interaction and (2) the cleavage sequence of calpain (PLFAER), which is highly sensitive to $\mathrm{Ca}^{2+}$ increase and allows injury-specific activation of Nrf2. In pretreatment studies, the DEETGE-CAL-Tat peptide at doses of 30,50 , or $100 \mu \mathrm{g}$ was dissolved in $5 \mu \mathrm{l}$ of $0.9 \%$ saline and was injected by unilateral intracerebroventricular administration $30 \mathrm{~min}$ before ischemia. For intracerebroventricular injection, the rats were placed on ear bars of a stereotaxic instrument under anesthesia and the peptide was injected into the left lateral ventricle (anteroposterior, $0.8 \mathrm{~mm}$; lateral, $1.5 \mathrm{~mm}$; depth, 3.5 $\mathrm{mm}$; from bregma) through a stepper-motorized microsyringe (Stoelting) at a rate of $1 \mu \mathrm{l} / \mathrm{min}$. To further confirm the effective neuroprotection, the DEETGE-CAL-Tat peptide dissolved at doses 1 or $2 \mathrm{mg}$ in 100 $\mu \mathrm{l}$ of saline (120 and $240 \mu \mathrm{g} / \mathrm{d}$ ) was subcutaneously administrated using a minipump ( $0.5 \mu \mathrm{l} / \mathrm{h}$ for $14 \mathrm{~d}$; Alzet 2002) beginning at $1 \mathrm{~d}$ after reperfusion and continued until the end of the experiment. Vehicle-treated control rats received an equal volume of $0.9 \%$ saline. The Morris water maze (MWM) test was performed on day 7, 8, and 9 after ischemia, as described previously by our group and others (Wang et al., 2013; Zhang et al., 2013). 
To show specificity of the DEETGE-CAL-Tat effects, several groups of controls were administrated by unilateral intracerebroventricular administration $(50 \mu \mathrm{g}$, in $5 \mu \mathrm{l}$ of $0.9 \%$ saline) $30 \mathrm{~min}$ before ischemia, including (1) DEETGE-Tat (to show it was indeed inactive), (2) scrambled-CAL-Tat (GEEDTE-CAL-Tat, to demonstrate the requirement of DEETDE for neuroprotection), (3) CAL-Tat (to rule out the possibility that the neuroprotection was not a result of CAL sequencemediated inhibition of calpain's ability to cleave its substrate proteins), and (4) Tat (trans-activator of transcription) sequence alone (to rule out a neuroprotective effect of Tat alone).

Histological analysis. The rats were killed under general anesthesia at various time points as mentioned in the figures, and transcardially perfused with $0.9 \%$ saline followed by $4 \%$ paraformaldehyde in $0.1 \mathrm{M}$ phosphate buffer $(\mathrm{PB}), \mathrm{pH}$ 7.4. Brains were postfixed in the same fixative at $4^{\circ} \mathrm{C}$ for $12 \mathrm{~h}$, cryoprotected in $30 \%$ sucrose in $\mathrm{PB}$, and then were cut longitudinally into 25 or $10 \mu \mathrm{m}$ sections with a cryostat. Coronal sections were collected through the entire dorsal hippocampus (2.5-4.5 $\mathrm{mm}$ posterior from bregma) to investigate the neuroprotective effect of DEETGE-CAL-Tat peptide following GCI by performing double immunofluorescence staining for NeuN, a neuronal marker, and TUNEL, a DNA damage and apoptosis marker (TUNEL kit, lot \#1639496, Life Technologies). Briefly, the sections $(25 \mu \mathrm{m})$ were washed using $0.1 \mathrm{M}$ PBS for $30 \mathrm{~min}$, permeabilized with $0.4 \%$ Triton X-100-PBS for $1 \mathrm{~h}$, blocked in $10 \%$ donkey serum for $1 \mathrm{~h}$, and then incubated in anti-NeuN antibody (1:800) overnight at $4^{\circ} \mathrm{C}$. After rinsing three times over $40 \mathrm{~min}$ with $0.1 \%$ Triton X-100-PBS, the sections were incubated with secondary antibodies (Alexa Fluor $488 \mathrm{~nm}$ donkey anti-mouse IgG) at room temperature for $1 \mathrm{~h}$ followed by washing for $4 \times 10 \mathrm{~min}$ in $0.1 \%$ Triton X-100-PBS. The sections were incubated in terminal deoxynucleotidyl transferase (TdT) reaction buffer $\mathrm{A}$ for $10 \mathrm{~min}$ at $37^{\circ} \mathrm{C}$ and then in $\mathrm{TdT}$ reaction mixture, including enzyme solution, for $1 \mathrm{~h}$ at $37^{\circ} \mathrm{C}$. After 5 min washing with distilled water, the sections were incubated in Click-iT Plus TUNEL reaction mixture for $30 \mathrm{~min}$ at $37^{\circ} \mathrm{C}$, washed with $0.1 \%$ Triton $100-\mathrm{PBS}$ over $20 \mathrm{~min}$, and then mounted on slides covered with water-based mounting medium. Images were captured under laser scanning confocal microscopy (LSCM, Olympus FV1000) and analysis was performed using digital imaging software (FV10-ASW 1.5). For cresyl violet (CV) staining, sections $(10 \mu \mathrm{m})$ were mounted on a slide and immersed in $0.1 \% \mathrm{CV}$ solution for $30 \mathrm{~min}$ after washing in $0.1 \mathrm{~m}$ PBS $15 \mathrm{~min}$. Then the slide was immersed in a container with distilled water for $2 \mathrm{~min}$ followed by dipping in 70 and $90 \%$ ethanol for 2 min each, followed by two immersions in $100 \%$ ethanol for $5 \mathrm{~min}$ each. The final two immersions were in $100 \%$ xylene solution for $5 \mathrm{~min}$ each. The slide was then coverslipped with permanent mounting medium. The slides were examined with a microscope (Olympus DP80) equipped with image-capture software (Cellsens 1.8). Well-rounded cells with no pyknosis stand for survival cells.

The number of NeuN-positive or TUNEL-positive neurons in immunofluorescent staining, or survival cells in CV staining per $250 \mu \mathrm{m}$ length of the medial CA1 pyramidal cell layer was bilaterally counted in five sections per animal and was averaged to provide the mean value. A mean \pm SD was calculated from the data in each group and statistical analysis performed as described below.

Immunofluorescence staining. The coronal sections $(25 \mu \mathrm{m})$ were washed for $30 \mathrm{~min}$ with $0.1 \mathrm{M}$ PBS, permeabilized using $0.4 \%$ Triton $\mathrm{X}-100-\mathrm{PBS}$ for $1 \mathrm{~h}$, and then incubated with $10 \%$ normal donkey serum for $1 \mathrm{~h}$ at room temperature. The sections were incubated with corresponding primary antibodies [anti-4HNE (1:200), anti-8OHdG (1:200), anti-Nrf2 (1:100), and anti-NeuN (1:800)] overnight at $4^{\circ} \mathrm{C}$, washed for $3 \times 10$ min with $0.1 \%$ Triton X-100-PBS, and then incubated with secondary antibodies (Alexa Fluor $568 \mathrm{~nm}$ donkey anti-mouse, Alexa Fluor $568 \mathrm{~nm}$ donkey anti-rabbit, and Alexa Fluor $488 \mathrm{~nm}$ donkey anti-mouse) at room temperature for $1 \mathrm{~h}$, followed by a final washing for $5 \times 10 \mathrm{~min}$ in $0.1 \%$ Triton X-100-PBS. DAPI ( $1 \mathrm{ng} / \mu \mathrm{l})$ was incubated for counterstaining of the nucleus. Sections were mounted with water-based mounting medium containing anti-fading agents (Biomeda, Fisher Scientific). The confocal images were captured on an LSCM (Olympus FV1000) and digital imaging software (FV10-ASW 1.5 Viewer).

Duolink In Situ hybridization. Interaction of Nrf2 and Keap1 in hippocampal CA1 region was determined by the Duolink II proximity liga- tion assay kit (PLA-probe anti-rabbit plus, catalog \#DUO92002-30RXN; PLA-probe anti-goat minus, catalog \#DUO92006-30RXN; Detection Kit Orange, catalog \#DUO92008-100RXN). The Duolink proximity ligation assay (DPLA) probe anti-rabbit plus binds to the Nrf2 antibody, whereas the PLA probe anti-goat minus binds to Keapl antibody. The DPLA secondary antibodies generate only a signal when the two DPLA probes are bound, which only takes place if both proteins are closer than $40 \mathrm{~nm}$, indicating their interaction. Briefly, the coronal sections were pretreated the same as indicated above for immunofluorescence staining. After blocking in $10 \%$ donkey serum, the sections were coincubated with primary antibodies of $\mathrm{Nrf} 2(1: 50)$ and Keap1 (1:50) overnight at $37^{\circ} \mathrm{C}$ in a preheated humidity chamber. After washing three times in buffer A for 10 min, Duolink II PLA probes detecting rabbit or goat secondary antibodies were diluted in the blocking agent in a concentration of 1:5 and applied to the sections, followed by incubation for $1 \mathrm{~h}$ in a preheated humidity chamber at $37^{\circ} \mathrm{C}$. Unbound DPLA probes were removed by washing three times in buffer A for $5 \mathrm{~min}$. The sections were incubated with the ligation solution consisting of Duolink II Ligation stock (1:5) and Duolink Ligase (1:40) diluted in high purity water for $30 \mathrm{~min}$ at $37^{\circ} \mathrm{C}$. After ligation, the Duolink Amplification and Detection stock was diluted $1: 5$ by the addition of polymerase (1:80), and then applied to the sections for $100 \mathrm{~min}$. After washing three times with buffer B for $2 \mathrm{~min}$, the sections were mounted on the slides and incubated with DAPI for the identification of nuclei. Images were captured using a Zeiss Icore-510 upright confocal scanning laser microscope, using a $40 \times$ oil-immersion objective and 1.0 $\times$ digital zoom. Confocal $z$-stacks of $2 \mu \mathrm{m}$ thicknesses were taken with a $z$-step of $0.1 \mu \mathrm{m}$ at $512 \times 512$ pixels, and a frame average of four. All $z$-stacks were captured from the depth of $10-12 \mu \mathrm{m}$ below the surface to ensure that sampling was done from the same level of antibody penetration for all animals. We quantified the number of Duolink puncta per image using ImageJ software (V1.47H) as described previously (Trifilieff et al., 2011; Calabrese et al., 2014).

Brain homogenates and subcellular fractionations. The rats were killed under anesthesia at 3, 6, 12, 24, and $72 \mathrm{~h}$ after ischemia. The hippocampal CA1 region was quickly dissected and the cytosolic or nuclear extraction was performed as described by previously (Wang et al., 2013). Briefly, the tissues were homogenized in ice-cold homogenization medium consisting of (in mM) the following: 50 HEPES, pH 7.4, $150 \mathrm{NaCl}, 1$ $\beta$-glycerophosphate, 3 dithiotheitol (DTT), 2 sodium orthovanadate $\left(\mathrm{Na}_{3} \mathrm{VO}_{4}\right), 1$ EGTA, $1 \mathrm{NaF}, 1$ phenylmethylsulfonyl fluoride (PMSF), $1 \%$ Triton X-100, and inhibitors of proteases and enzymes (Thermo, LI150825) with a Teflon-glass homogenizer. The homogenates were centrifuged at $15,000 \times g$ for $30 \mathrm{~min}$ at $4^{\circ} \mathrm{C}$, and then supernatants were collected and stored at $-80^{\circ} \mathrm{C}$ for use. When necessary, cytosol fractions and nuclear fractions were extracted. Briefly, tissues were homogenized in ice-cold buffer A containing (in mM) the following: 10 HEPES, pH 7.9, 1 DTT, $1 \mathrm{Na}_{3} \mathrm{VO}_{4}$, 1,4-nitrophenyl phosphate (PNPP), and inhibitors of proteases and enzymes. The homogenates were allowed to swell on ice for $10 \mathrm{~min}$. Then, tubes were vigorously vortexed for $30 \mathrm{~s}$ and centrifuged at $800 \times g$ for $10 \mathrm{~min}$ after the addition of NP-40 ( $0.6 \%$ of total solution). Supernatants were centrifuged at $15,000 \times g$ for $30 \mathrm{~min}$ at $4^{\circ} \mathrm{C}$. The nuclear pellets were washed three times with buffer $\mathrm{A}$ and resuspended in buffer B [(in mM) 20 HEPES, pH 7.9, $400 \mathrm{NaCl}, 20 \%$ glycerine, 1 DTT, 1 $\left.\mathrm{Na}_{3} \mathrm{VO}_{4}, 1 \mathrm{PNPP}\right]$ with inhibitors of proteases and enzymes, and then the tubes were vigorously rocked at $4^{\circ} \mathrm{C}$ for $30 \mathrm{~min}$. After centrifugation at $12,000 \times g$ for $15 \mathrm{~min}$, the nuclear extracts were aliquoted and frozen in liquid nitrogen and stored at $-80^{\circ} \mathrm{C}$ until use. An enhanced BCA protein assay kit with bovine serum albumin (BSA) as the standard was used to determine the protein concentrations.

Western blotting analysis. Protein from each sample was heated at $100^{\circ} \mathrm{C}$ for 5 min with loading buffer containing $0.125 \mathrm{M}$ Tris- $\mathrm{HCl}, \mathrm{pH} 6.8$, $20 \%$ glycerol, $4 \%$ SDS, $10 \%$ mercaptoethanol, and $0.002 \%$ bromphenol blue, then separated by SDS-PAGE using $10 \%$ acrylamide gels (50 $\mu \mathrm{g}$ per lane). Then proteins were transferred into a PVDF membrane using a wet transfer system at $100 \mathrm{~V}$ for $40 \mathrm{~min}$. PVDF membranes were blocked using 3\% BSA, $0.2 \%$ Tween 20 in Tris-buffered saline for $\geq 30 \mathrm{~min}$ at room temperature and incubated overnight at $4^{\circ} \mathrm{C}$ with following primary antibodies: Nrf2 (1:200), HO-1 (1:200), NQO1 (1:200), GPx1 (1: 500), SOD2 (1:200), NeuN (1:1000), and $\beta$-actin (1:500). Alkaline 
phosphatase-conjugated IgG was used as secondary antibody and BCIP/ NBT was used as color substrate. NeuN and $\beta$-actin were used as loading controls for the nuclear and cytosol or total protein, respectively. The bands on the membranes were scanned and analyzed with the ImageJ analysis software (version 1.30v; Wayne Rasband, National Institutes of Health). To quantitate hippocampal protein abundance, band densities for the indicated phosphoprotein were normalized to the corresponding band densities for total protein signals, and the indicated total proteins were expressed relative to $\beta$-actin or NeuN signals. Normalized means were then expressed as fold changes of the corresponding value for control (sham operated) animals. A mean $\pm \mathrm{SD}$ was calculated from the data from all of the animals for graphical presentation and statistical comparison.

Coimmunoprecipitation analysis. For immunoprecipitation (IP), tissue homogenates (400 $\mu \mathrm{g}$ of protein) were diluted fourfold with HEPES buffer containing 50 mM HEPES, pH 7.4, $150 \mathrm{~mm} \mathrm{NaCl}, 10 \%$ glycerol, $1 \%$ Triton X-100, and $1 \mathrm{~mm}$ each of EGTA, EDTA, PMSF, and $\mathrm{Na}_{3} \mathrm{VO}_{4}$. Samples were preabsorbed for $1 \mathrm{~h}$ with $20 \mu \mathrm{l}$ of protein $\mathrm{A} / \mathrm{G}$, and then centrifuged to remove any protein adhered nonspecifically to the protein A/G. The supernatant was incubated with $2 \mu \mathrm{g}$ of Keap1 (\#4617) antibody or nonspecific IgG with gentle rotation for overnight at $4^{\circ} \mathrm{C}$. After the addition of protein A/G-Sepharose, the mixture was incubated at $4^{\circ} \mathrm{C}$ for an additional $4 \mathrm{~h}$. Samples were washed with IP buffer $2 \min \times 3$. After centrifuge at $4^{\circ} \mathrm{C}, 12,000 \times g \times 2 \mathrm{~min}$, the samples were diluted with $2 \times$ loading buffer and boiled for $5 \mathrm{~min}$. SDS-PAGE for Nrf2 or IgG was carried out.

Nrf2 DNA-binding activity assay. Nrf2 DNA-binding activity was detected using a Trans-AM Nrf2 assay kit following the protocol of the manufacturer (catalog \#50296, Active Motif). Briefly, $40 \mu \mathrm{l}$ of complete binding buffer was mixed with $10 \mu \mathrm{l}$ of protein sample (containing $20 \mu \mathrm{g}$ of protein) and incubated for $1 \mathrm{~h}$ at room temperature with mild agitation. For positive or blank control, $10 \mu \mathrm{l}$ of the provided nuclear extract or complete binding buffer was used instead of the protein samples. After washing, $100 \mu \mathrm{l}$ of diluted Nrf2 antibody (1:1000) was added to each well and incubated for $1 \mathrm{~h}$, followed by incubation with $100 \mu \mathrm{l}$ of diluted HRP-conjugated antibody (1:1000) for another $1 \mathrm{~h}$. Developing solution $(100 \mu \mathrm{l})$ was added to each well and incubated at room temperature until the blue color turned medium to dark blue. Stop solution was then added and absorbance was read on a spectrophotometer at $450 \mathrm{~nm}$ with a reference wavelength of $655 \mathrm{~nm}$. Nrf2 DNA-binding activity was expressed as fold changes in absorbance compared with sham groups.

MWM test. The spatial learning and memory of the rats were evaluated by the MWM test as described previously by our laboratory and others (Wang et al., 2013; Zhang et al., 2013). The apparatus consisted of a black circular pool (diameter, $180 \mathrm{~cm}$; height $80 \mathrm{~cm}$ ) filled with water at 22$24^{\circ} \mathrm{C}$ to a height of $50 \mathrm{~cm}$. The pool was divided into four quadrants with a hidden platform ( $9 \mathrm{~cm}$ in diameter, $1.5-2.0 \mathrm{~cm}$ below the water line) placed in one of the quadrants. The rat was placed in the water facing the wall at one of four random start locations (first, second, third, and fourth quadrant, located at equal distances from each other on the pool rim). Each rat was allowed to find the submerged platform within $90 \mathrm{~s}$, and rest on it for $20 \mathrm{~s}$. If the rat failed to find the hidden platform within $90 \mathrm{~s}$, it was guided to the platform and placed on it for $20 \mathrm{~s}$. The procedure was repeated for all the four start locations. The latency time, representing the average of the four trails, to reach the platform and distance were recorded. Two sessions of four trials were conducted on the first testing day, and the interval was $4 \mathrm{~h}$. The first session was considered as a training procedure. The second session was formal testing and was conducted daily for the next $2 \mathrm{~d}$. Four hours after the last trial, a probe trial was performed within $90 \mathrm{~s}$ in which the platform was removed from the tank. The rat was placed in the water at the same random start location, and time spent in the quadrant that previously contained the platform was used to assess performance of learning and memory of the rats.

Statistical analysis. Data were expressed as mean \pm SD and analyzed using the one-way ANOVA program. Differences were considered significant at $p<0.05$ as determined using the Student-Newman-Keuls methods for pair-wide multiple comparisons.

\section{Results}

We first examined the ability of the DEETGE-CAL-Tat peptide $(50 \mu \mathrm{g})$ to exert neuroprotection in the hippocampal CA1 region when administered intracebroventrically into the lateral ventricle of adult male rats $30 \mathrm{~min}$ before GCI. To determine specificity of the effect, we also examined the effect of several control peptides (CAL-Scr-Tat, DEETGE-Tat, CAL-Tat, Tat; $50 \mu \mathrm{g}$ ). All animals were killed $7 \mathrm{~d}$ after GCI and hippocampal sections collected for immunohistochemistry. Immunostaining with the neuronal marker NeuN was used to examine the number of surviving cells in the CA1 region $7 \mathrm{~d}$ after 15 min GCI. Representative photomicrographs of NeuN (green) immunostaining for all groups are shown in Figure $1 A$, while quantification of results from all animals in each group is presented in Figure $1 B$ (NeuN, surviving cells). As shown in Figure 1 $A, B, 15$ min GCI [ischemia/reperfusion $(\mathrm{I} / \mathrm{R})]$ caused a profound decrease in surviving cells in the $\mathrm{CA} 1$ region at $7 \mathrm{~d}$, compared with the sham control. Administration of the DEETGE-CAL-Tat peptide $30 \mathrm{~min}$ before GCI was profoundly neuroprotective, while the control peptides (CALScr-Tat, DEETGE-Tat, CAL-Tat, Tat) had no significant effect upon the number of surviving cells in the hippocampal CA1 region, indicating the specificity of the DEETGE-CAL-Tat peptide effect.

We next performed a dose-response analysis for the DEETGE-CAL-Tat peptide in the GCI model using three doses (30, 50, and $100 \mu$ g, i.c.v.). Staining with the neuronal marker NeuN was used to examine the number of surviving cells in the CA1 region at $7 \mathrm{~d}$ after $15 \mathrm{~min}$ GCI. TUNEL staining was also used to determine the number of apoptotic cells in the CA1 region at $7 \mathrm{~d}$ after GCI. Representative photomicrographs of NeuN (green) and TUNEL (red) staining for all groups are shown in Figure $2 A$, while quantification of results from all animals in each group is presented in Figure $2 B$ (NeuN, surviving cells) and Figure $2 C$ (TUNEL, apoptotic cells). As shown in Figure $2 A-C, 15$ min GCI (I/R) caused a profound decrease in surviving cells and increase in apoptotic cells in the CA1 region at $7 \mathrm{~d}$, compared with the sham control. Administration of the DEETGE-CAL-Tat peptide $30 \mathrm{~min}$ before GCI was profoundly neuroprotective and antiapoptotic at all doses tested, compared with the vehicle control group. Of the three doses, the $50 \mu \mathrm{g}$ dose of the DEETGECAL-Tat peptide was most effective, followed by the $30 \mu \mathrm{g}$ dose. The $100 \mu \mathrm{g}$ dose, while effective, had the lowest mean number of surviving neurons compared with the other doses. Its ability to reduce the number of apoptotic cells was also moderate compared with the $50 \mu \mathrm{g}$ dose. Based on these findings, we chose to use the $50 \mu \mathrm{g}$ dose of the DEETGE-CAL-Tat peptide for all of the remaining experiments in the study (except for the final experiment where post-treatment and peripheral administration of the DEETGE-CAL-Tat peptide was examined).

We next examined the effect of the DEETGE-CAL-Tat peptide on preserving cognitive function following GCI. This was accomplished by intracerebroventricular administration of the DEETGE-CAL-Tat peptide 30 min before GCI and then examining spatial learning and memory in the rats at days 7,8 , and 9 after GCI reperfusion using the MWM test. As shown in Figure $3 A-C$, compared with sham control, animals that underwent $15 \mathrm{~min}$ GCI displayed a significant increase in latency to find the platform (Fig. $3 A$ ) in the MWM, and a significant decrease in time spent in the platform quadrant (Fig. $3 B$ ). As shown in Figure $3 A-C$, DEETGE-CAL-Tat peptide-treated animals displayed significant cognitive improvements as evidenced by DEETGE-CALTat peptide-treated animals exhibiting a significantly decreased 
A

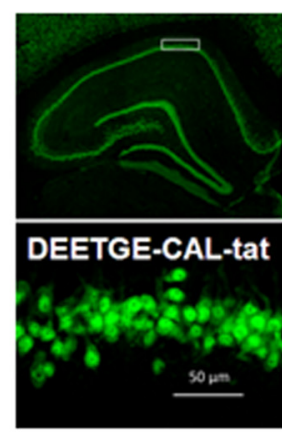

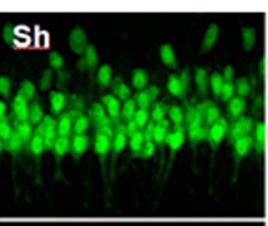
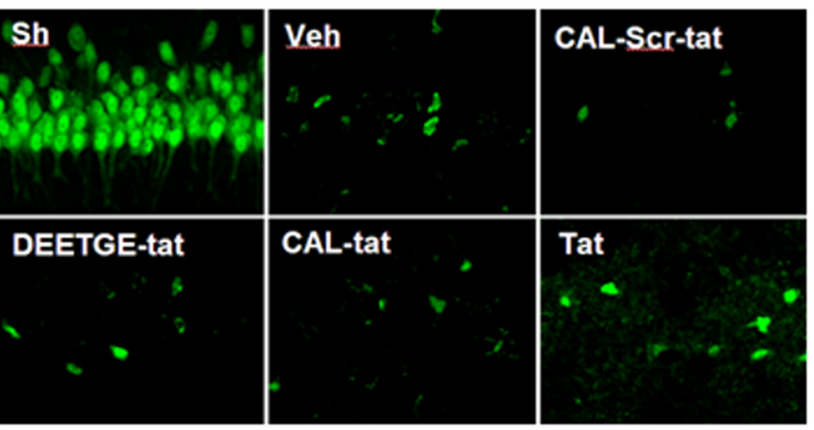

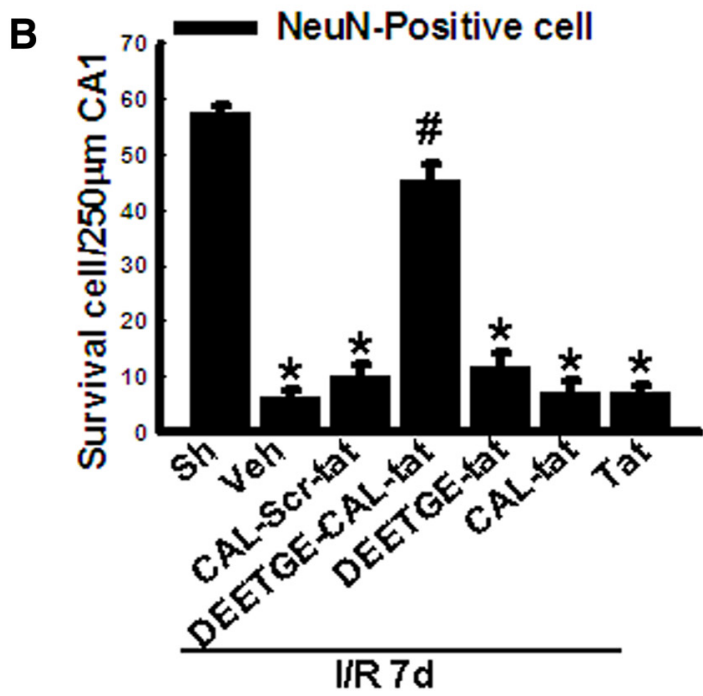

Figure 1. Examination of the neuroprotective ability of the DEETGE-CAL-Tat peptide and various control peptides following GCI Adult male rats were injected intracebroventrically with either DEETGE-CAL-Tat peptide or control peptides (CAL-SCr-Tat, DEETGETat, (AL-Tat, Tat) at 30 min before $\mathrm{GCl}$ and the neuroprotective effect was examined in the hippocampal CA1 region. $A$, Representative hippocampal CA1 sections from sham-operated (Sh), DEETGE-CAL-Tat-treated ( $50 \mu \mathrm{g})$, vehicle-treated (Veh; $0.9 \% \mathrm{NaCl}$ ), or control-treated (CAL-SCr-Tat, DEETGE-Tat, CAL-Tat, Tat; $50 \mu \mathrm{g}$ ) animals were subjected to immunofluorescent staining for NeuN (green, indicating surviving cells) at $7 \mathrm{~d}$ after $\mathrm{GCl}$ reperfusion. $\boldsymbol{B}$, Quantification was performed by counting the number of NeuN-positive neurons per $250 \mu$ m length in the medial CA1 pyramidal cell layer $(n=5-6) .{ }^{*} p<0.05$ compared with Sh group, $\# p<0.05$ compared with Veh group. Scale bar, $50 \mu \mathrm{m}$. Magnification, $40 \times$.

latency to find the platform (Fig. 3A), and a significantly increased time spent in the platform quadrant (Fig. $3 B$ ), compared with the I/R and vehicle controls. Representative tracings indicating sample paths of the rats from the maze latency trials and swimming traces from probe trials are shown in Figure 3C. Figure $4 A-D$ shows the effect of the DEETGE-CAL-Tat peptide on neuronal survival and cognitive function in sham, nonischemic rats examined using CV staining or the MWM test, respectively. As shown in Figure $4 A-D$, the DEETGE-CAL-Tat peptide had no significant effect in sham nonischemic animals upon neuronal survival (Fig. 4A), latency to find the platform (Fig. 4B), time spent in the platform quadrant (Fig. $4 C$ ), or swim tracings (Fig. $4 D$ ), compared with sham controls.

We next examined the efficacy of the DEETGE-CAL-Tat peptide to induce activation of $\mathrm{Nrf} 2$ in the hippocampal CA1 region after GCI by examining three endpoints: (1) nuclear translocation of Nrf2 (Fig. $5 A-C$ ), (2) total Nrf2 protein levels (Fig. 5D,E), (3) DNA binding of Nrf2 (Fig. $5 F$ ), and (4) induction of Nrf2regulated proteins (Fig. 6). As shown in Figure $5 A, B$, hippocampal CA1 nuclear and cytoplasmic extracts were subjected to Western blot analysis for Nrf2 at various time points after GCI and in sham animals. The results revealed that Nrf2 protein levels decreased in the cytosolic fractions at $6,12,24$, and $72 \mathrm{~h}$ after GCI reperfusion (Fig. $5 A, B$ ). In contrast, Nrf2 levels in the CA1 region increased in the nuclear fraction at $6,12,24$, and $72 \mathrm{~h}$ after GCI reperfusion, but not at $3 \mathrm{~h}$, compared with vehicle controls (Fig. $5 A, B$ ). The increase in Nrf2 levels in the nuclear fractions correlates well with the temporal pattern of Nrf2 decrease in the cytosolic fractions. The results suggest that the DEETGE-CAL-Tat peptide strongly increases Nrf2 translocation to the nucleus in ischemic animals from 6 to $72 \mathrm{~h}$ after GCI reperfusion. We also used double immunohistochemistry for Nrf2 and NeuN, a nuclear neuronal marker, to determine whether DEETGE-CAL-Tat peptide treatment induced $\mathrm{Nrf} 2$ expression and nuclear translocation in neurons at $24 \mathrm{~h}$ after GCI reperfusion. As shown in Figure $5 C$, Nrf2 expression in the hippocampal CA1 region of sham and vehicle animals was primarily cytoplasmic in neuronal fibers and did not colocalize in the nucleus with NeuN. In contrast, DEETGE-CALTat peptide-treated animals showed high Nrf2 translocation to the nucleus of neurons at $24 \mathrm{~h}$ after GCI reperfusion, as evidenced by $\mathrm{Nrf2}$ staining being highly colocalized with NeuN. While DEETGECAL-Tat peptide treatment enhanced Nrf2 translocation to the nucleus after GCI, it did not significantly affect total Nrf2 levels in the hippocampal CA1 region at $24 \mathrm{~h}$ after GCI (Fig. 5D,E). Translocation of Nrf2 to the nucleus is typically associated with it assuming its well known transcriptional role. To explore this possibility, we examined Nrf2 binding to DNA in hippocampal CA1 samples using an Nrf2/ARE-binding assay. As shown in Figure 5F, DEETGE-CAL-Tat peptide-treated animals had a $\sim 2.0-2.7$-fold increase in DNA-binding activity of Nrf2 at 24 and $72 \mathrm{~h}$ after GCI reperfusion, compared with vehicle and sham controls. This agrees well with the nuclear translocation of Nrf2 observed in DEETGE-CAL-Tat peptide-treated animals at these same times (Fig. 5A-C).

We next performed coimmunoprecipitation (Co-IP) to examine the efficacy of the DEETGE-CAL-Tat peptide to decrease Keap1Nrf2 protein interaction in the hippocampal CA1 region. Cytosolic fractions collected from the hippocampal CA1 region at $24 \mathrm{~h}$ after GCI were used for the Co-IP studies. Sham and vehicle controls were also included. As shown in Figure 6A, DEETGE-CAL-Tat treatment markedly decreased Keap1 interaction with Nrf2 in the cytoplasm of hippocampal CA1 region at $24 \mathrm{~h}$ after GCI, compared with I/R, vehicle, and sham controls. Figure $6 B$ demonstrates that the subfractionation method we used to obtain the cytosolic and nuclear fractions produced highly purified cytosolic and nuclear fractions, as determined by use of a specific cytosolic marker, $\beta$-actin, and nuclear marker NeuN. To confirm the in vitro Co-IP results, we performed an in vivo Duo-Link II in situ proximity ligation assay using primary antibodies for Keap1 and Nrf2. The Duolink procedure is based on the use of two probes that consist of a secondary antibody attached to a unique synthetic oligonucleotide, which acts as a re- 
A
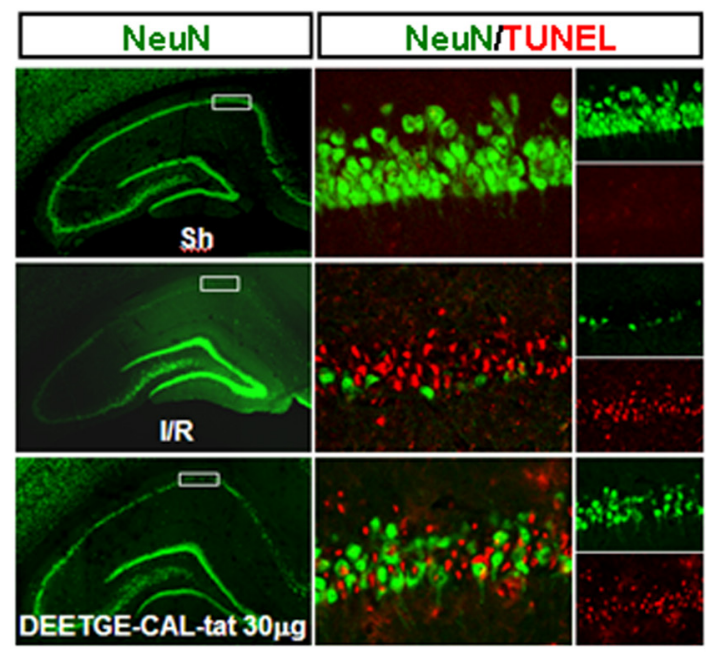

B

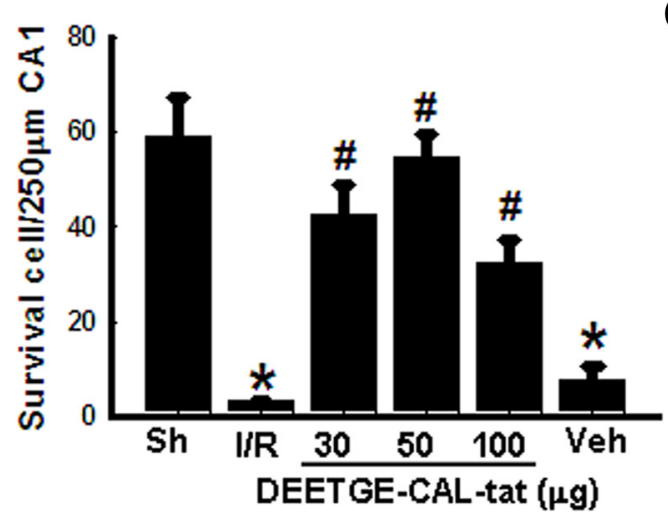

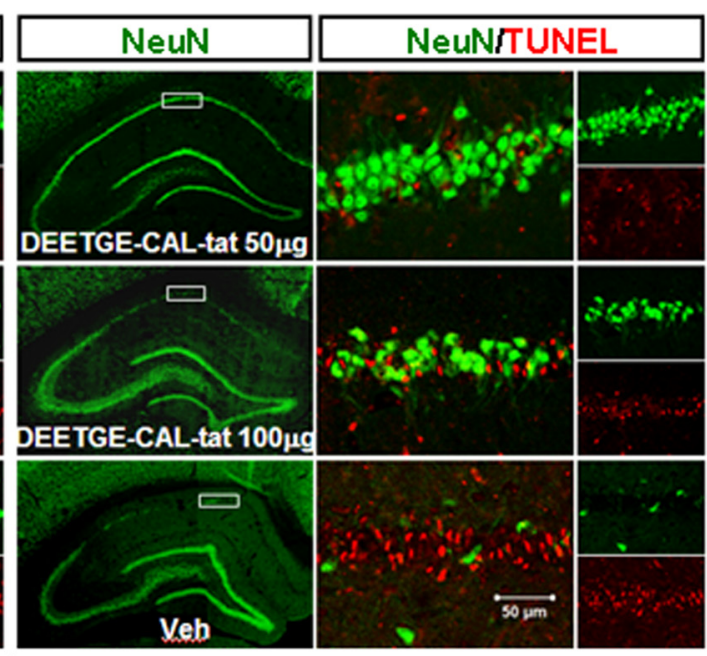

C

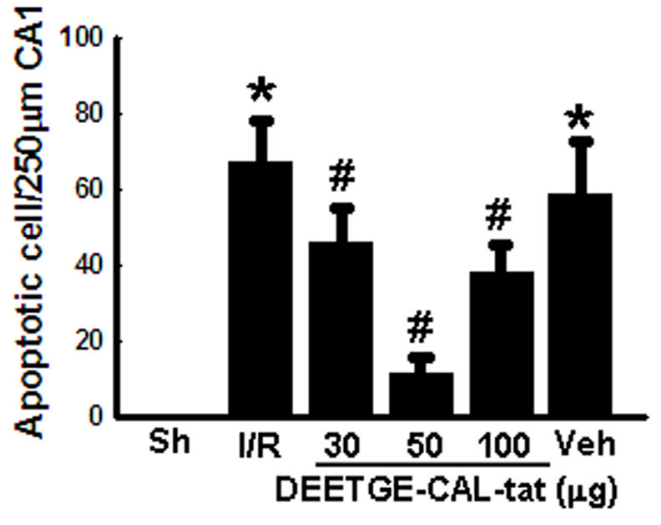

Figure 2. Dose-response characteristics for DEETGE-CAL-Tat peptide neuroprotection of hippocampal CA1 neurons following GCI. Adult male rats were injected intracebroventrically with various doses of the DEETGE-CAL-Tat peptide at 30 min before $\mathrm{GCl}$ and the neuroprotective effect examined in the hippocampal CA1 region at $7 \mathrm{~d}$ after $\mathrm{GCl}$. $A$, Representative hippocampal CA1 sections from sham (Sh), I/R, DEETGE-CAL-Tat (30,50, $100 \mu \mathrm{g}$ ), or vehicle (Veh; $0.9 \% \mathrm{NaCl}$ ) were subjected to double staining for NeuN (green, indicating surviving cells) and TUNEL (red, indicating apoptotic cells). $\boldsymbol{B}, \boldsymbol{C}$, Quantification was performed by counting the number of NeuN-positive neurons $(\boldsymbol{B})$ and TUNEL-positive neurons $(\boldsymbol{C})$ per $250 \mu \mathrm{m}$ length in the medial $\mathbf{C A} 1$ pyramidal cell layer $(n=5-6){ }^{*} p<$ 0.05 compared with Sh group, \#p < 0.05 compared with Veh groups. Scale bar, $50 \mu \mathrm{m}$. Magnification, $40 \times$.

porter. When the two target antigens come into sufficient proximity to interact with one another, it generates a fluorescent signal. Amplification is provided by DNA ligation and polymerization, which allows detection of single events. The number of Duolink puncta per image field was quantified as described previously (Trifilieff et al., 2011; Calabrese et al., 2014) and as described in the Materials and Methods. Figure $6 \mathrm{C}$ shows representative photomicrographs for Duolink puncta in the hippocampal CA1 region, while Figure $6 D$ shows quantification of the number of Duolink puncta. Light staining with DAPI was used to show cell nuclei. As shown in Figure $6 C, D$, the results of the Duo-Link II in situ proximity ligation assay revealed that while the number of Duolink puncta between sham and vehicle and I/R controls did not differ significantly in the hippocampal CA1 regions at $24 \mathrm{~h}$ after GCI. However, DEETGE-CALTat peptide treatment significantly decreased the number of Duolink puncta, as compared with the vehicle and I/R controls.

To confirm the functional importance of the increased Nrf2 DNA binding, we examined protein expression of four known cytoprotective and antioxidative Nrf2 transcriptional targets: NQO1, HO-1, GPx1, and SOD2. As shown in Figure $7 A-E$, Western blot analysis of hippocampal CA1 protein samples revealed that DEETGE-CAL-Tat peptide-treated animals had a significant increase of HO-1 (Fig. $7 A, B$ ), NQO1 (Fig. $7 A, C$ ), and GPx1 (Fig. $7 A, D$ ) protein levels at 6,24 , and $72 \mathrm{~h}$ after GCI reperfusion, compared with vehicle controls. SOD2 protein levels were also significantly increased in DEETGECAL-Tat peptide-treated animals at 24 and $72 \mathrm{~h}$, but not at $6 \mathrm{~h}$ after GCI reperfusion (Fig. $7 \mathrm{~A}, \mathrm{E}$ ).

Since Nrf2 activation is well known to exert an antioxidant effect in cells through induction of the above genes, as well as other target genes, we examined whether DEETGE-CAL-Tat peptide treatment could attenuate GCI-induced oxidative damage in the hippocampal CA1 region. Toward this end, we used immunofluorescent staining of hippocampal CA1 sections to determine immunoreactive levels of the oxidative stress markers $4 \mathrm{HNE}$ and $8 \mathrm{OHdG}$ (red). DAPI staining (green) was also used to visualize the nucleus of cells. As shown in Figure $8 A, B$, as expected, sham (nonischemic) animals had very low to undetectable immunostaining for the oxidative stress markers $4 \mathrm{HNE}$ and $8 \mathrm{OHdG}$ in the hippocampal CA1 region at 24 and $72 \mathrm{~h}$ after sham surgery, respectively. In contrast, ischemic animals (vehicle group) showed an increase in $4 \mathrm{HNE}$ immunostaining in the hippocampal CA1 region at 24 and $72 \mathrm{~h}$ after GCI reperfusion, which was markedly attenuated by DEETGE-CAL-Tat peptide treatment. A pattern for increase of $8 \mathrm{OHdG}$ levels was also evident at both time points after GCI, but only the $72 \mathrm{~h}$ time point increase was statistically significant compared with the sham control. DEETGE-CAL-Tat peptide treatment markedly inhibited the increase of $8 \mathrm{OHdG}$ levels at $72 \mathrm{~h}$. 

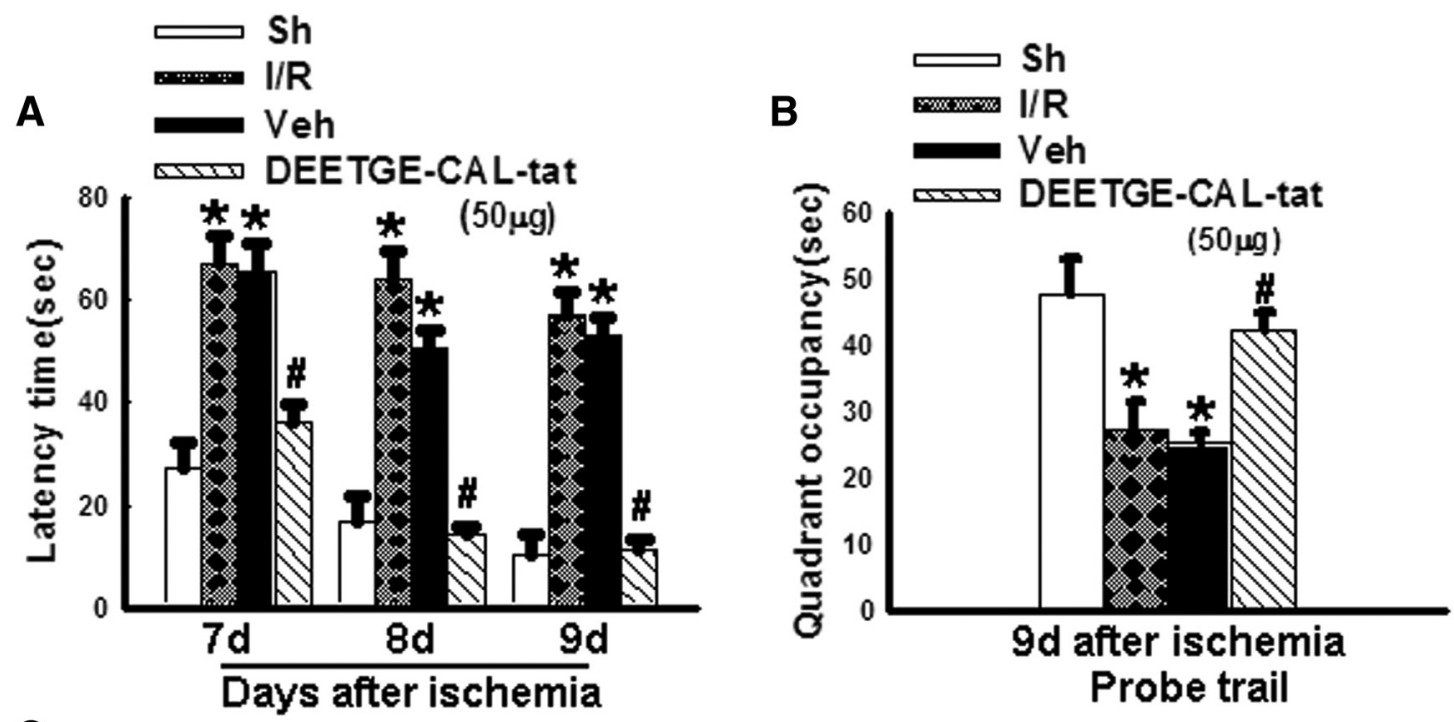

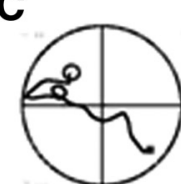

(a)

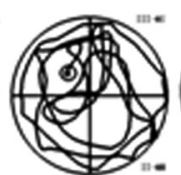

(b)

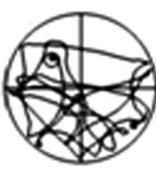

(c)

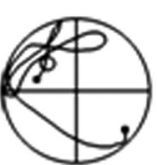

(d)

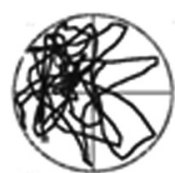

(e)

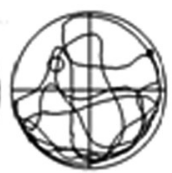

(f)

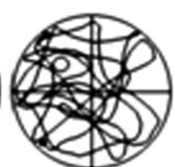

(g)

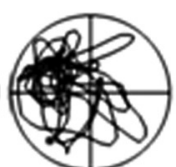

(h)

Figure 3. DEETGE-CAL-Tat peptide treatment preserves hippocampal-dependent cognitive function following GCl. $\boldsymbol{A}, \boldsymbol{B}$, Latency trial $(\boldsymbol{A})$ and probe trial $(\boldsymbol{B})$ results of sham $($ Sh), I/R, vehicle (Veh, $0.9 \%$ saline), and DEETGE-CAL-Tat (50 $\mu \mathrm{g}$ ) pretreatment animals in the MWM. $\boldsymbol{A}$, Time [in seconds (sec)] spent finding the submerged platform at day 7,8 , and 9 after ischemic injury. $\boldsymbol{B}$, Exploration time spent in the quadrant that initially contained the platform at day 9 following reperfusion. $C$, Representative traces indicating the sample paths of the rats from the maze latency trials (a- $d$ ) and the swimming traces from probe trials (e-h). a, e: Sh; b, f: l/R; $c$, g: Veh; d, h: DEETGE-CAL-Tat). Data are expressed as mean \pm SD from five different animals. ${ }^{*} p<0.05$ vs Sh group; \#p $<0.05$ vs Veh group.

A

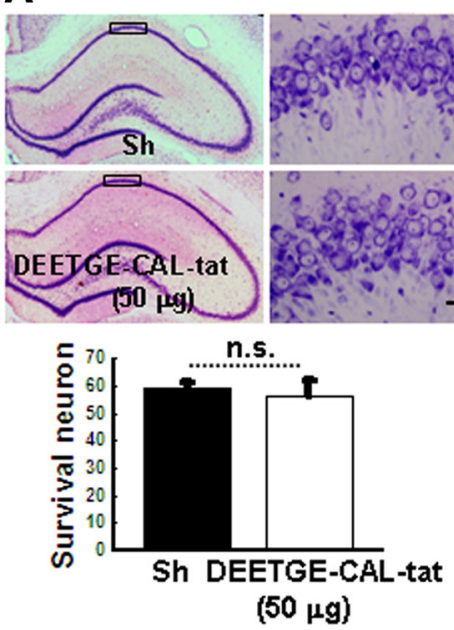

B

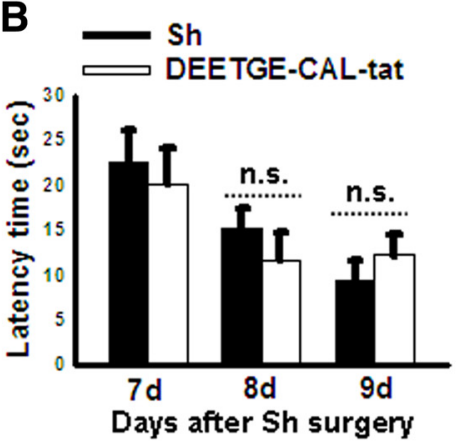

D

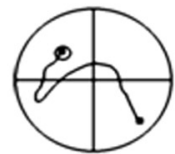

(a)

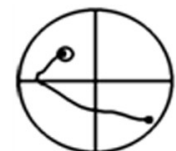

(b)

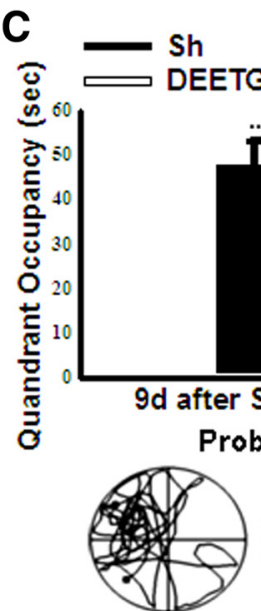

(c)

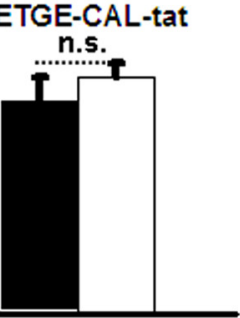

Probe trial

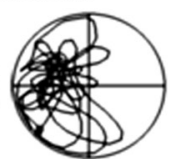

(d)

Figure 4. DEETGE-CAL-Tat peptide treatment does not affect neuronal survival or cognitive function in nonischemic animals. $\boldsymbol{A}$, Representative hippocampal CA1 sections from sham and DEETGE-CAL-Tat $(50 \mu \mathrm{g})$ treatment (nonischemic) groups were subjected to CV staining. $\boldsymbol{B}, \boldsymbol{C}$, Latency trial $(\boldsymbol{B})$ and probe trial $(\boldsymbol{C})$ results in the MWM for the two groups. $\boldsymbol{B}$, Time [in seconds (sec)] spent finding the submerged platform at 7,8, and $9 \mathrm{~d}$ after sham surgery. $\boldsymbol{C}$, Exploration time spent in the quadrant that initially contained the platform at $9 \mathrm{~d}$ following reperfusion. $\boldsymbol{D}$, Representative traces indicating the sample paths of the rats from the maze latency trials $(a, b)$, and the swimming traces from probe trials $(c, d)$. a, c: sham; $b$, d: DEETGE-CAL-Tat. Data are expressed as mean \pm SD from five different animals. n.s., No significant change between the two groups. Magnification: $4 \times$ in left line and 20X in right line. Scale bar, $50 \mu \mathrm{m}$.

Finally, while the above studies show that pretreatment is strongly neuroprotective and able to preserve cognitive function, it would be more therapeutically relevant if DEETGE-CAL-Tat peptide treatment could be administered postischemia, and peripherally rather than centrally, to protect the brain and maintain cognitive function after GCI. We therefore sought to determine the neuroprotective and cognitive-preserving effect of periph- eral, postischemia administration of DEETGE-CAL-Tat peptide following GCI. DEETGE-CAL-Tat peptide (120 and $240 \mu \mathrm{g} / \mathrm{d}$ ) or vehicle was administered subcutaneously via miniosmotic pumps implanted under the skin in the midback region. DEETGE-CAL-Tat peptide was administered beginning $1 \mathrm{~d}$ after GCI reperfusion, and continued until the end of the experiment (day 9 after reperfusion). As shown in Figure 9B, GCI reperfusion 

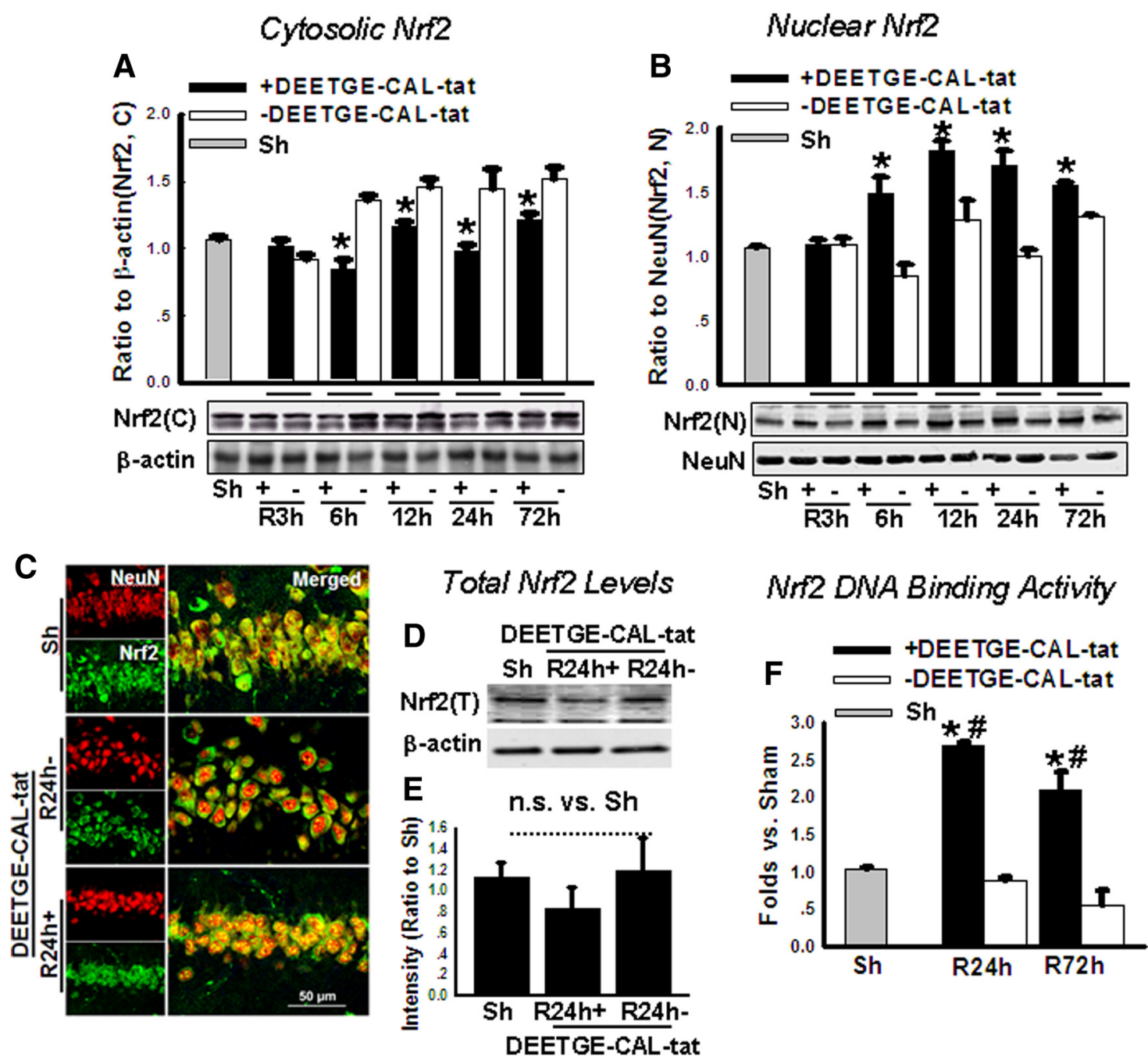

Figure 5. DEETGE-CAL-Tat peptide treatment enhances Nrf2 nuclear translocation and DNA binding in the hippocampal CA1 region following GCI. The cytoplasm or nuclear extracts were subjected to Western blot analysis for Nfr2 at indicated time points after reperfusion with or without DEETGE-CAL-Tat pretreatment. $\boldsymbol{A}, \boldsymbol{B}$, Data analyses of Nrf2 protein from the cytoplasmic extracts $(\boldsymbol{A})$ or nuclear extracts $(\boldsymbol{B})$ were expressed as ratios to $\beta$-actin or NeuN and the analysis was represented by means \pm SD from four independent animals. C, Confocal analysis for NeuN (green), Nrf2 (red), and merged images in the hippocampal CA1 region following sham $(\mathrm{Sh})$ treatment, $24 \mathrm{~h}$ after reperfusion with DEETGE-CAL-Tat treatment, or $24 \mathrm{~h}$ after reperfusion without DEETGE-CAL-Tat treatment. $\boldsymbol{D}$, Western blot analysis of DEETGE-CAL-Tat effect upon total Nrf2 protein levels in the hippocampal CA1 region after GCl. $\boldsymbol{E}$, Quantification of Western blot data shown in $\boldsymbol{D}$. $\boldsymbol{F}$, Effect of DEETGE-CAL-Tat upon DNA-binding activity of Nrf2, as determined using a TransAM Nrf2 assay kit. ${ }^{*} p<0.05$ compared with the same time point for groups without DEETGE-CAL-Tat treatment, $\# p<0.05$ compared with Sh group. Magnification, $40 \times$. Scale bar, $50 \mu \mathrm{m}$.

led to a dramatic loss of NeuN-positive cells in the CA1 region and a robust increase of apoptotic cells at $9 \mathrm{~d}$ after reperfusion, as evidenced by TUNEL staining, compared with the sham control. Furthermore, DEETGE-CAL-Tat peptide administration peripherally from 1 to $9 \mathrm{~d}$ after GCI was strongly neuroprotective at the $240 \mu \mathrm{g} / \mathrm{d}$ dose, but not at the $120 \mu \mathrm{g} / \mathrm{d}$ dose, as evidenced by the increase in the number of NeuN-positive cells, while simultaneously decreasing the number of TUNEL-positive cells in the CA1 region at the $240 \mu \mathrm{g} / \mathrm{d}$ dose at $9 \mathrm{~d}$ after GCI.

We next examined the ability of postischemia peripheral administration of the $240 \mu \mathrm{g} / \mathrm{d}$ dose of DEETGE-CAL-Tat peptide to preserve spatial learning and memory in rats at days 7,8 , and 9 after GCI reperfusion. In these studies, the MWM was used to access spatial learning and memory. As shown in Figure $9 C, D$, GCI resulted in a significant increase in latency to find the platform (Fig. 9C) in the MWM, and a significant decrease in time spent in the platform quadrant (Fig. 9D), compared with sham controls. Intriguingly, peripheral, postischemia treatment with the $240 \mu \mathrm{g} / \mathrm{d}$ dose of DEETGE-CAL-Tat peptide strongly pre- served cognitive function after GCI, as evidenced by DEETGECAL-Tat peptide-treated animals exhibiting a significantly decreased latency to find the platform (Fig. 9C), and a significantly increased time spent in the platform quadrant (Fig. 9D), compared with the vehicle controls. Representative tracings indicating sample paths of the rats from the maze latency trials and swimming traces from probe trials are shown in Figure 9E, $F$.

\section{Discussion}

The current study provides evidence that a novel cell-permeable Nrf2 activation peptide, DEETGE-CAL-Tat, has efficacy as a potential therapy for hippocampal neuroprotection and cognitive preservation following GCI. Both centrally administered pretreatment, as well as peripherally administered post-treatment, exerted robust neuroprotection of the vulnerable hippocampal CA1 region and preserved cognitive function in adult rats following GCI. While previous work had shown that the DEETGECAL-Tat peptide could reduce blood-brain barrier compromise after traumatic brain injury, our study is the first to demonstrate 

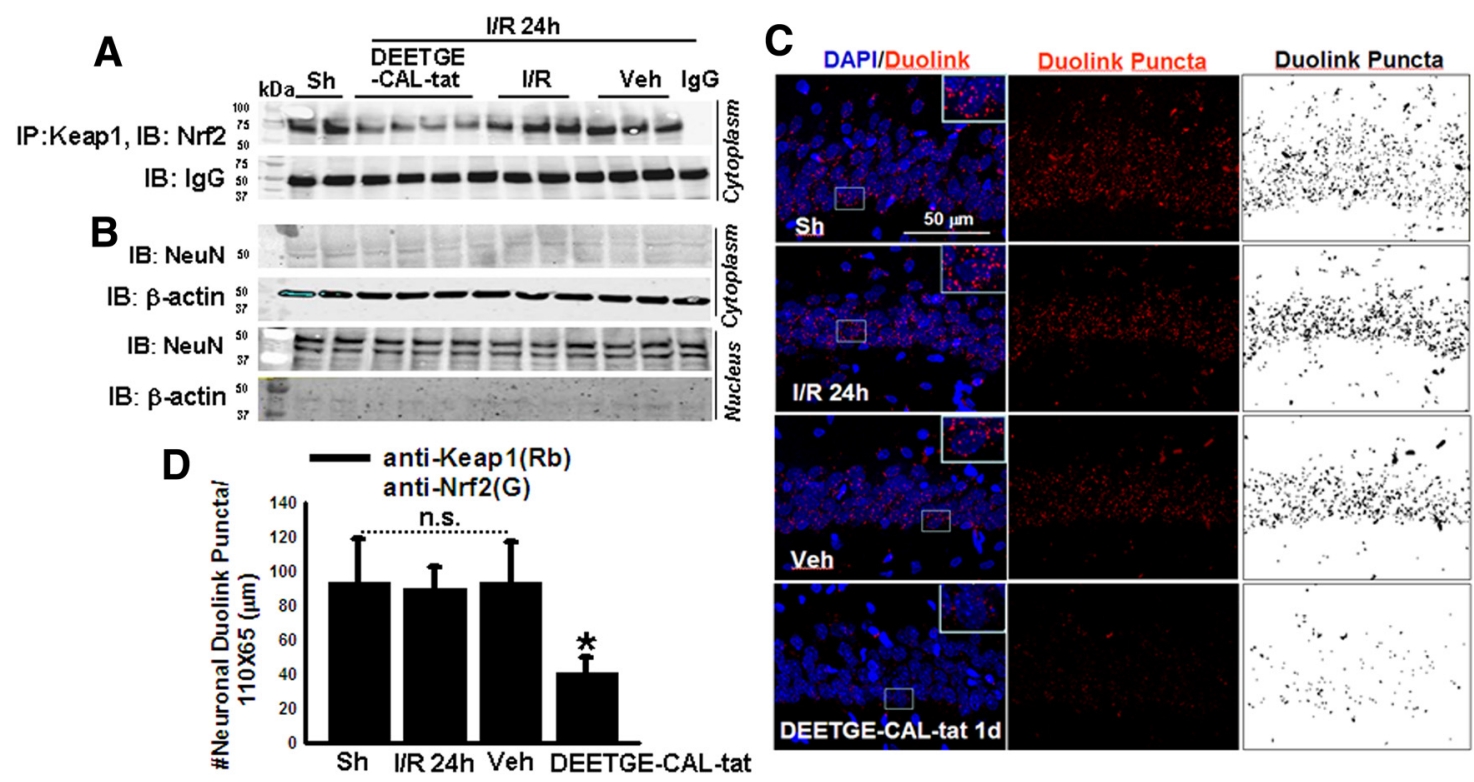

Figure 6. DEETGE-CAL-Tat peptide decreases interaction of Keap1 with Nrf2 in the cytoplasm at $24 \mathrm{~h}$ after GCI reperfusion. $A$, IP for Keap1 and immunoblotting for Nrf2 reveals that DEETGECAL-Tat peptide treatment markedly reduces the interaction of Keap1 with Nrf2 in the cytoplasm of hippocampal CA1 region samples. $B$, Immunoblotting of the samples for either $\beta$-actin, a cytoplasmic marker, or for NeuN, a nuclear marker, showing the purity of the cytoplasmic and nuclear fractions. C, Duo-Link II in situ proximity ligation assay using Keap1 and Nrf2 antibodies reveals that Duolink puncta in the hippocampal CA1 regions at $24 \mathrm{~h}$ after GCl is markedly decreased by DEETGE-CAL-Tat peptide treatment, compared with vehicle and I/R controls. For clarity, both color and black-and-white images of the Duolink puncta are provided. $\boldsymbol{D}$, Quantification of the Duolink puncta in C confirms that DEETGE-CAL-Tat peptide treatment significantly reduced interaction of Keap1 and Nrf2 in the hippocampal CA1 region at $24 \mathrm{~h}$ after GCl, compared with vehicle and I/R controls. ${ }^{*} p<0.05$ compared with all other groups. $N=5-6 / \mathrm{group}$. Scale bar, $50 \mu \mathrm{m}, \mathrm{Magnification}, 40 \times$.

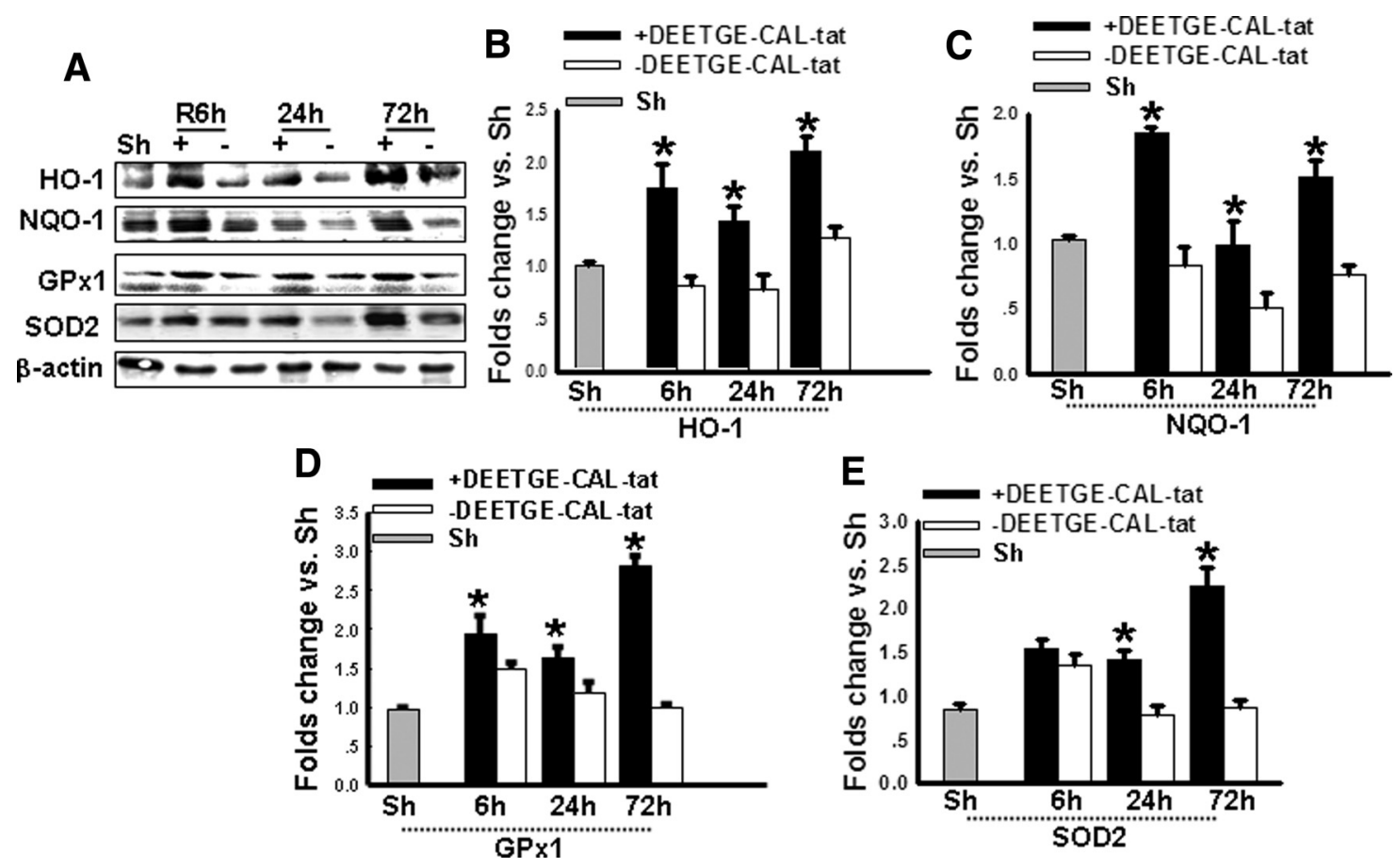

Figure 7. DEETGE-CAL-Tat peptide treatment enhances expression of Nrf2-regulated antioxidant genes in the hippocampal CA1 region following $\mathrm{GCl}$. $A$, Total protein from sham (Sh), I/R, and DEETGE-CAL-Tat treatment rats were subjected to Western blotting for the Nrf2-regulated genes: HO-1, NQO1, GPX1, SOD2. $\beta$-Actin expression was used for the loading control. B-E, Quantification of blots depicted in $A$. Data are expressed as fold changes versus $S h$ (means $\pm S D, n=4$ in each group). ${ }^{*} p<0.05$ compared with the same time point of group without DEETGE-CAL-Tat treatment (I/R).

a neuroprotective and cognitive-enhancing effect of the DEETGE-CAL-Tat peptide in the ischemic brain. Our findings have potentially important translational relevance because current therapies for GCI have been reported to have poor efficacy, and thus there is a strong need for new therapeutic approaches (Nielsen et al., 2011; Kim et al., 2012).
The neuroprotective effect of the DEETGE-CAL-Tat peptide in our study appeared specific, as the control peptides (DEETGE-Tat, CAL-Scrambled-Tat, CAL-Tat, and Tat) showed no significant neuroprotective effect. The lack of a significant neuroprotection by the control DEETGE-Tat peptide, which might have been expected to have some activity, is 


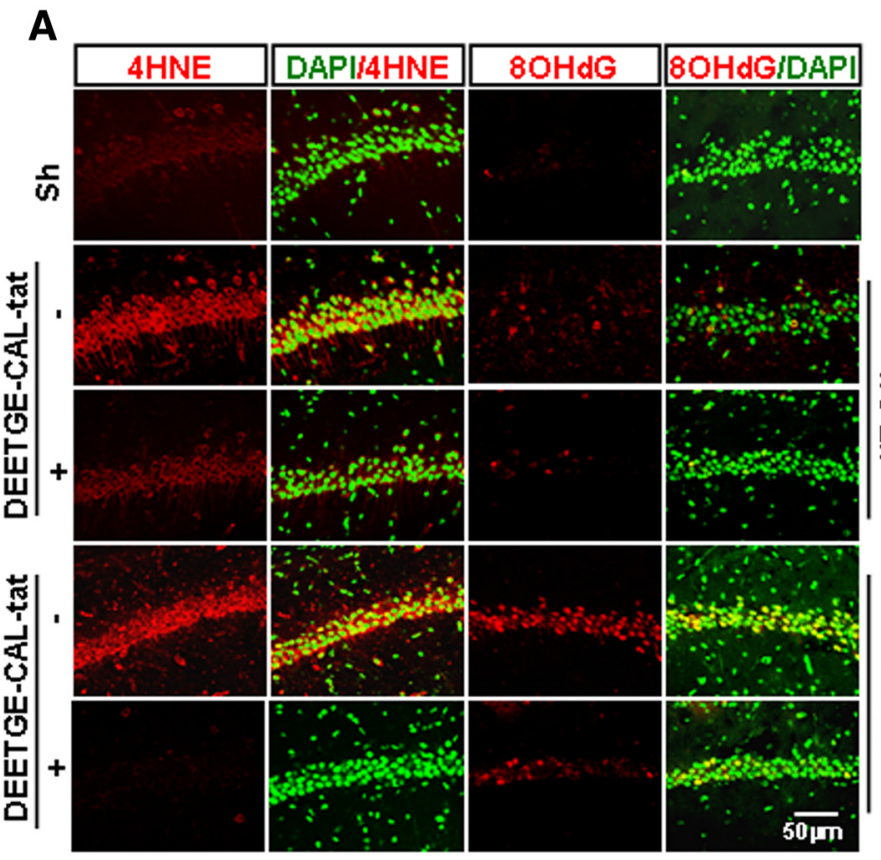

\section{B}

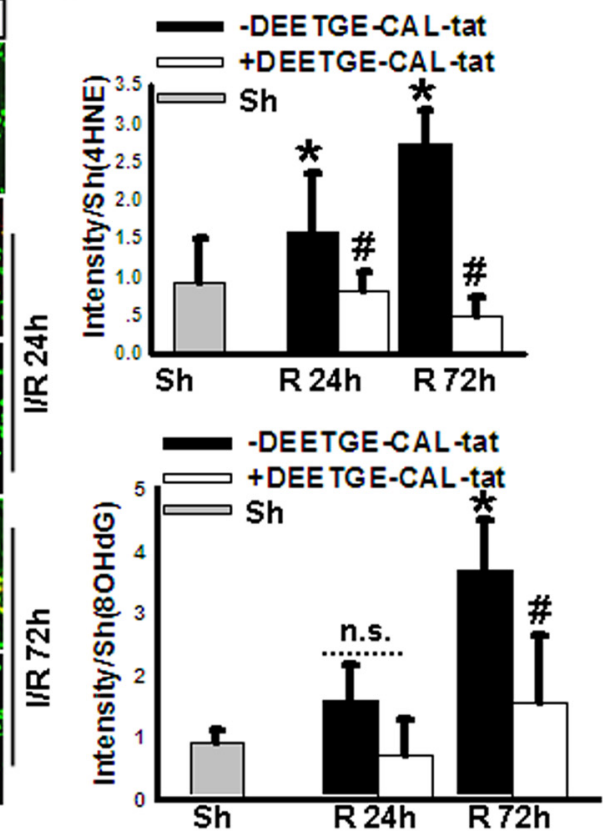

Figure 8. DEETGE-CAL-Tat peptide treatment attenuates oxidative stress damage in the hippocampal CA1 region following GCl.A, Coronal hippocampal CA1 sections obtained from sham-treated (Sh), I/R-treated (Veh), or DEETGE-CAL-Tat (50 $\mu \mathrm{g}$ )-treated animals at reperfusion 24 or $72 \mathrm{~h}$ after GCl were subjected to immunostaining for the oxidative stress markers $4 \mathrm{HNE}$ or $80 \mathrm{HdG}$ (red). DAPI was converted to green for better viewing. $\boldsymbol{B}$, Fluorescence intensity for 4HNE or $80 \mathrm{HdG}$ staining, expressed as arbitrary units ratio to Sh, was measured in hippocampal CA1 region, and data shown are representative as mean \pm SD from five independent animals ( $n=5$ in each group). ${ }^{*} p<0.05$ versus Sh groups, $\# p<0.05$ versus I/R (Veh) without DEETGE-CAL-Tat treatment $(-D E E T G E-$ (AL-Tat). Magnification, $40 \times$. Scale bar, $50 \mu \mathrm{m}$.

most likely due to inefficient release of the transduction domain (Tat), and a suboptimal DEETGE accumulation in the cytoplasm. A similar conclusion was reached by Zhao et al. (2011) when they tested the DEETGE-Tat peptide for ability to activate Nrf2 target genes in the brain following traumatic brain injury and found no effect, while in contrast, the DEETGE-CAL-Tat peptide strongly induced Nrf2 target genes in their study. We believe the reason the DEETGE-CAL-Tat peptide was effective while the DEETGE-Tat peptide was not is that the calpain cleavage site between the Tat and DEETGE motifs in the DEETGE-CAL-Tat peptide allows for the removal of the protein transduction domain (Tat) and facilitates cytoplasmic accumulation of the DEETGE-containing peptide. This suggestion is also supported by the fact that the DEETGE-CAL-Tat peptide was inactive in the noninjured brain where calpain activity would be low and no or little cleavage of the transduction domain would occur. From a therapeutic standpoint, the injury-specific activation of the DEETGE-CAL-Tat peptide is a unique and attractive feature, as it restricts Nrf2 nuclear activation to brain areas that are injured, thereby providing for less chance of unwanted side effects.

An additional important point to consider is that a higher dose of DEETGE-CAL-Tat peptide was needed for peripheral, postischemia treatment $(240 \mu \mathrm{g} / \mathrm{d})$ compared with centrally administered pretreatment $(50 \mu \mathrm{g})$. The higher dose needed for postischemia treatment is most likely due to the peripheral route of administration in which higher concentrations are needed to reach an optimal level in the brain. Other studies have used a similar dose range for peripheral administration of Tat-fusion peptides after ischemia, and demonstrated effective uptake into brain neurons (Cao et al., 2002; Yin et al., 2006; Krautwald et al., 2010). While there is controversy on whether Tat-fused peptides are significantly taken up by brain cells in the basal noninjured state, ischemic injury has been shown to significantly enhance Tat-fusion peptide entry into the brain (Simon et al., 2010). The increased uptake of Tat-fused peptides after ischemic injury is reportedly due to disruption of the blood-brain barrier, which undergoes a prolonged disruption after GCI (Mossakowski et al., 1994; Preston and Webster, 2004).

While our study showed the effectiveness of the DEETGECAL-Tat peptide administered continuously beginning $1 \mathrm{~d}$ after GCI, more detailed work will be needed to carefully define the exact therapeutic window for post-treatment effectiveness. For instance, it remains to be determined whether DEETGE-CALTat peptide administration can be delayed even further beyond the $1 \mathrm{~d}$ post-GCI used in our study and still be effective. It might also be advantageous to test other administration routes for posttreatment, such as the intranasal administration route, which has recently emerged as a potentially effective route for delivery of drugs to the brain. Future studies in our laboratory will address these issues.

With respect to the molecular mechanisms underlying the beneficial effects of the DEETGE-CAL-Tat peptide, our study supports induction of downstream Nrf2 antioxidant target genes as a potential key mediator of its beneficial neuroprotective and cognitive-enhancing effects. In support of this contention, our study revealed that the DEETGE-CAL-Tat peptide markedly decreased interaction of Keap1 with Nrf2 in the cytoplasm, and correspondingly enhanced nuclear translocation and DNA binding of Nrf2 in the hippocampal CA1 region. Further work revealed that the nuclear translocation of Nrf2 occurred primarily in neurons in the hippocampal CA1 region, suggesting that beneficial effects of DEETGE-CAL-Tat peptide are exerted directly on neurons. Importantly, our study further showed that Nrf2 activation following DEETGE-CAL-Tat peptide treatment was 
A

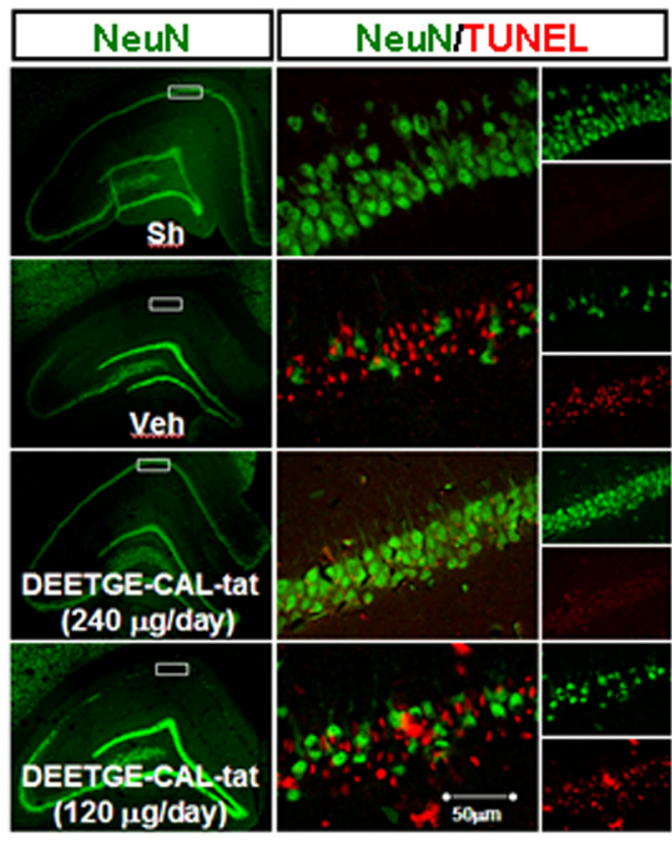

C

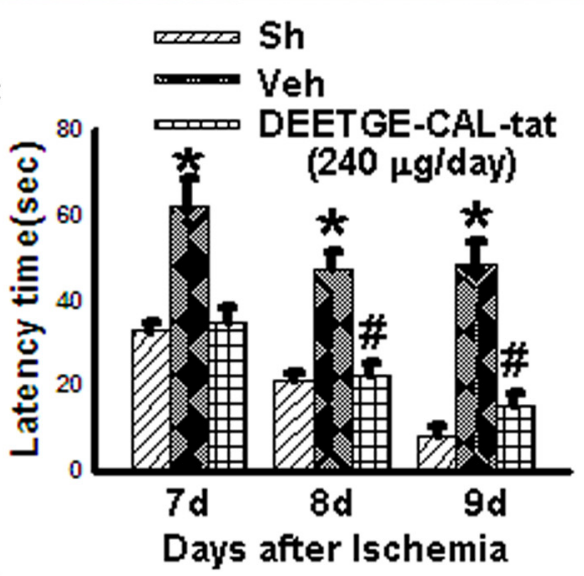

E

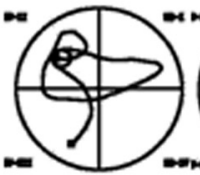

(a)

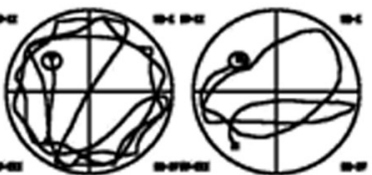

(b) (c)
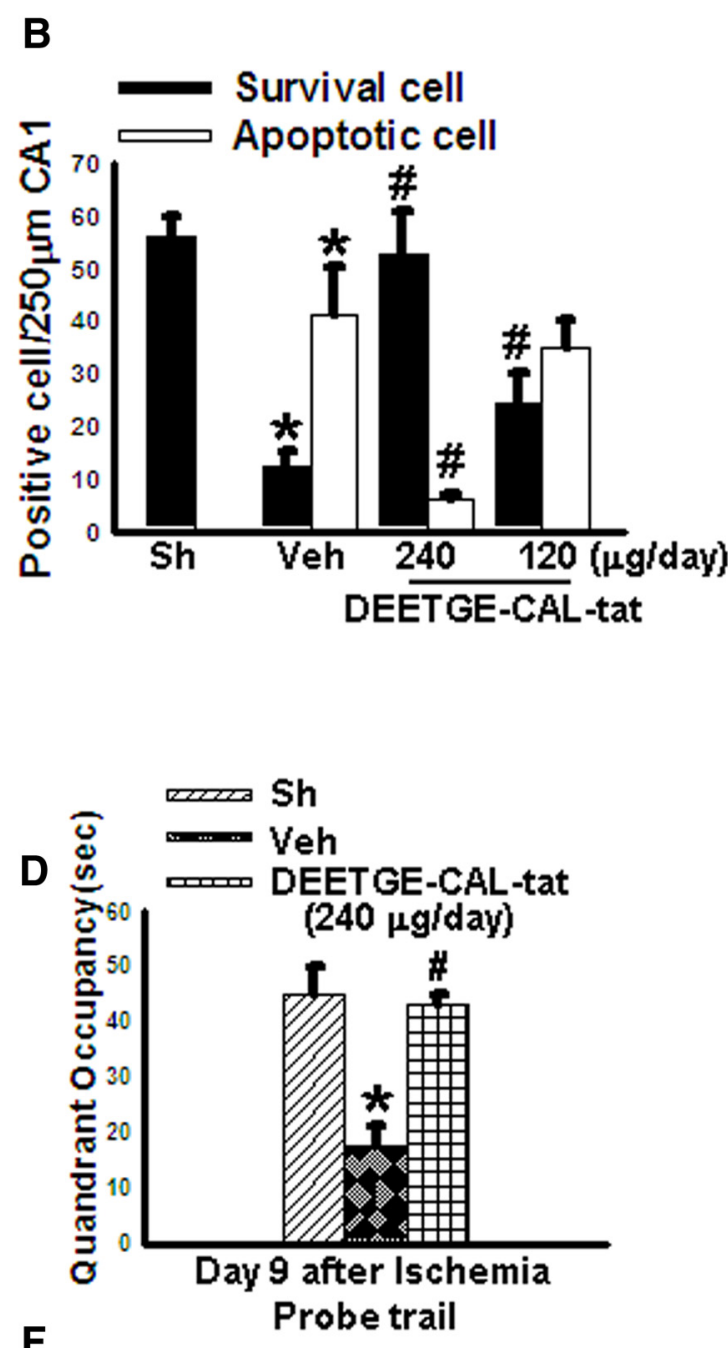

$\mathbf{F}$

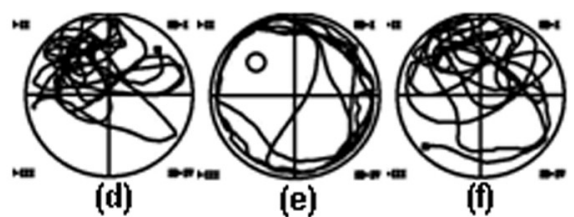

Figure 9. Post-treatment with the DEETGE-CAL-Tat peptide enhances neuronal survival and hippocampal-dependent cognitive function following GCI. DEETGE-CAL-Tat (120 or $240 \mu \mathrm{g} / \mathrm{d}$ ) or vehicle (Veh; $0.9 \% \mathrm{NaCl}$ ) was administrated subcutaneously using a minipump (Alzet 2002, $0.5 \mu \mathrm{l} / \mathrm{h}$ for $14 \mathrm{~d}$ ) beginning at $1 \mathrm{~d}$ after reperfusion. The MWM was performed during days $7-9$, and double staining for NeuN (green) and TUNEL (red) at $9 \mathrm{~d}$ after ischemia. $\boldsymbol{A}$, Representative hippocampal CA1 area stained with NeuN (green) and TUNEL (red). $\boldsymbol{B}$, Quantification was performed by counting the number of NeuN-positive cells and TUNEL-positive cells per $250 \mu$ m length in the medial CA1 pyramidal cell layer ( $n=5$. Scale bar, $50 \mu \mathrm{m}) .{ }^{*} p<0.05$ compared with sham (Sh) group, $\# p<0.05$ compared with vehicle (Veh) groups. C, MWM results. Time [in seconds (sec)] spent finding the submerged platform at day 7, 8, and 9 after ischemic injury. $\boldsymbol{D}$, Exploration time spent in the quadrant that initially contained the platform at day 9 following reperfusion. $E-F$, Representative traces indicating the sample paths of the rats from the maze latency trials (a-c) and the swimming traces from probe trials (d-f). a, d: Sh; b, e:Veh;c, f: $240 \mu \mathrm{g} / \mathrm{d}$ DEETGE-CAL-Tat treatment. Data are expressed as mean \pm SD from five different animals. ${ }^{*} p<0.05$ versus Sh group, and $\# p<0.05$ versus Veh group.

correlated with strong induction of several known Nrf2 target antioxidant genes, such as NQO1, HO-1, GPxl, and SOD2.

In accordance with its induction of Nrf2 activation, the DEETGE-CAL-Tat peptide exerted a robust attenuation of oxidative DNA damage and lipid peroxidative damage in hippocampal CA1 neurons after GCI, as measured by immunofluorescence staining of the oxidative stress markers $8 \mathrm{OHdG}$ and 4-HNE. The antioxidant effects of the DEETGE-CAL-Tat peptide are likely due to the upregulation of the Nrf2-regulated antioxidant genes NQO1, GPX1, and SOD2 by the DEETGE-CAL-Tat peptide. Of these Nrf2-regulated antioxidant factors, $\mathrm{HO}-1$ has been implicated to be particularly important in neuroprotection against cerebral ischemia, as evidenced by the fact that pharmacological induction of HO-1 protects hippocampal CA1 neurons from GCI-induced delayed neuronal cell death (Zhang et al., 2012), and by the finding that HO-1 knock-out mice exhibit greater ischemic damage compared with wild-type mice (Shah et al., 2011). An important role of the other Nrf2-regulated factors is also supported, as overexpression of GPxl has been shown to markedly inhibit cell death and to reduce astrocyte activation 
after cerebral ischemia (Ishibashi et al., 2002). Correspondingly, GPx1 knock-out mice have been reported to exhibit increased infarct size and exacerbated apoptosis after cerebral ischemia (Crack et al., 2001). Finally, overexpression of SOD2 has also been shown to reduce neuronal vulnerability to forebrain ischemia (Xu et al., 2010), further supporting the importance of Nrf2 antioxidant defensive mechanisms against ROS-induced injury. The fact that the DEETGE-CAL-Tat peptide can upregulate all these antioxidant factors, as well as potentially a whole battery of other antioxidant, neuroprotective, and metabolism-related genes that are known to be target genes for Nrf2, suggests that a collective effect to regulate a broad array of Nrf2 genes is likely to underlie its robust neuroprotection and cognitive-preserving effects in GCI.

In conclusion, the current study demonstrates that the DEETGE-CAL-Tat peptide can enhance Nrf2 activation and antioxidant gene induction in the hippocampus after GCI, resulting in robust neuroprotection and preservation of cognitive function. A unique feature of the peptide, which is not present in other Nrf2 activators or other Tat-fused peptides, is that its beneficial effects are injury specific. This feature is attractive as it targets drug activation specifically in the site of injury, and likely would lead to a reduction of undesirable side effects if translatable to the clinic. Due to its injury-specific activation, robust neuroprotection, and cognitive-preserving effects, the DEETGE-CALtat peptide may represent a much-needed therapeutic advance that could have efficacy in the treatment of GCI.

\section{References}

Beerens AM, Al Hadithy AF, Rots MG, Haisma HJ (2003) Protein transduction domains and their utility in gene therapy. Curr Gene Ther 3:486494. CrossRef Medline

Brillman J (1993) Central nervous system complications in coronary artery bypass graft surgery. Neurol Clin 11:475-495. Medline

Calabrese B, Saffin JM, Halpain S (2014) Activity-dependent dendritic spine shrinkage and growth involve downregulation of cofilin via distinct mechanisms. PloS One 9:e94787. CrossRef Medline

Cao G, Pei W, Ge H, Liang Q, Luo Y, Sharp FR, Lu A, Ran R, Graham SH, Chen J (2002) In vivo delivery of a Bcl-xL fusion protein containing the TAT protein transduction domain protects against ischemic brain injury and neuronal apoptosis. J Neurosci 22:5423-5431. Medline

Chen HH, Chen YT, Huang YW, Tsai HJ, Kuo CC (2012) 4-Ketopinoresinol, a novel naturally occurring ARE activator, induces the Nrf2/ HO-1 axis and protects against oxidative stress-induced cell injury via activation of PI3K/AKT signaling. Free Radic Biol Med 52:1054-1066. CrossRef Medline

Chen J, Zhu RL, Nakayama M, Kawaguchi K, Jin K, Stetler RA, Simon RP, Graham SH (1996) Expression of the apoptosis-effector gene, Bax, is up-regulated in vulnerable hippocampal CA1 neurons following global ischemia. J Neurochem 67:64-71. Medline

Crack PJ, Taylor JM, Flentjar NJ, de Haan J, Hertzog P, Iannello RC, Kola I (2001) Increased infarct size and exacerbated apoptosis in the glutathione peroxidase-1 (Gpx-1) knockout mouse brain in response to ischemia/ reperfusion injury. J Neurochem 78:1389-1399. CrossRef Medline

Guerrero-Beltrán CE, Calderón-Oliver M, Pedraza-Chaverri J, Chirino YI (2012) Protective effect of sulforaphane against oxidative stress: recent advances. Exp Toxicol Pathol 64:503-508. CrossRef Medline

Harukuni I, Bhardwaj A (2006) Mechanisms of brain injury after global cerebral ischemia. Neurol Clin 24:1-21. CrossRef Medline

Ishibashi N, Prokopenko O, Weisbrot-Lefkowitz M, Reuhl KR, Mirochnitchenko O (2002) Glutathione peroxidase inhibits cell death and glial activation following experimental stroke. Brain Res Mol Brain Res 109: 34-44. CrossRef Medline

Kam KY, Yu SJ, Jeong N, Hong JH, Jalin AM, Lee S, Choi YW, Lee CK, Kang SG (2011) p-Hydroxybenzyl alcohol prevents brain injury and behavioral impairment by activating Nrf2, PDI, and neurotrophic factor genes in a rat model of brain ischemia. Mol Cells 31:209-215. CrossRef Medline
Kim YM, Yim HW, Jeong SH, Klem ML, Callaway CW (2012) Does therapeutic hypothermia benefit adult cardiac arrest patients presenting with nonshockable initial rhythms?: A systematic review and meta-analysis of randomized and nonrandomized studies. Resuscitation 83:188-196. CrossRef Medline

Kirino T (1982) Delayed neuronal death in the gerbil hippocampus following ischemia. Brain Res 239:57-69. CrossRef Medline

Kirino T, Sano K (1984) Selective vulnerability in the gerbil hippocampus following transient ischemia. Acta Neuropathol 62:201-208. CrossRef Medline

Krautwald S, Ziegler E, Rölver L, Linkermann A, Keyser KA, Steen P, Wollert KC, Korf-Klingebiel M, Kunzendorf U (2010) Effective blockage of both the extrinsic and intrinsic pathways of apoptosis in mice by TAT-crmA. J Biol Chem 285:19997-20005. CrossRef Medline

McMahon M, Thomas N, Itoh K, Yamamoto M, Hayes JD (2004) Redoxregulated turnover of Nrf2 is determined by at least two separate protein domains, the redox-sensitive Neh2 degron and the redoxinsensitive Neh6 degron. J Biol Chem 279:31556-31567. CrossRef Medline

Mossakowski MJ, Lossinsky AS, Pluta R, Wisniewski HM (1994) Abnormalities of the blood-brain barrier in global cerebral ischemia in rats due to experimental cardiac arrest. Acta Neurochir Suppl (Wien) 60:274-276. Medline

Moulaert VR, Verbunt JA, van Heugten CM, Wade DT (2009) Cognitive impairments in survivors of out-of-hospital cardiac arrest: a systematic review. Resuscitation 80:297-305. CrossRef Medline

Nielsen N, Friberg H, Gluud C, Herlitz J, Wetterslev J (2011) Hypothermia after cardiac arrest should be further evaluated-a systematic review of randomised trials with meta-analysis and trial sequential analysis. Int J Cardiol 151:333-341. CrossRef Medline

Preston E, Webster J (2004) A two-hour window for hypothermic modulation of early events that impact delayed opening of the rat blood-brain barrier after ischemia. Acta Neuropathol 108:406-412. CrossRef Medline

Pulsinelli WA, Brierley JB, Plum F (1982) Temporal profile of neuronal damage in a model of transient forebrain ischemia. Ann Neurol 11:491498. CrossRef Medline

Roger VL, Go AS, Lloyd-Jones DM, Adams RJ, Berry JD, Brown TM, Carnethon MR, Dai S, de Simone G, Ford ES, Fox CS, Fullerton HJ, Gillespie C, Greenlund KJ, Hailpern SM, Heit JA, Ho PM, Howard VJ, Kissela BM, Kittner SJ, et al. (2011) Heart disease and stroke statistics-2011 update: a report from the American Heart Association. Circulation 123:e18 e209. CrossRef Medline

Roine RO, Kajaste S, Kaste M (1993) Neuropsychological sequelae of cardiac arrest. JAMA 269:237-242. CrossRef Medline

Sauvé MJ, Doolittle N, Walker JA, Paul SM, Scheinman MM (1996) Factors associated with cognitive recovery after cardiopulmonary resuscitation. Am J Crit Care 5:127-139. Medline

Shah ZA, Nada SE, Doré S (2011) Heme oxygenase 1, beneficial role in permanent ischemic stroke and in Gingko biloba (EGb 761) neuroprotection. Neuroscience 180:248-255. CrossRef Medline

Simon MJ, Kang WH, Gao S, Banta S, Morrison B 3rd (2010) Increased delivery of TAT across an endothelial monolayer following ischemic injury. Neurosci Lett 486:1-4. CrossRef Medline

Sun D, Gilboe DD (1994) Ischemia-induced changes in cerebral mitochondrial free fatty acids, phospholipids, and respiration in the rat. J Neurochem 62:1921-1928. Medline

Swain JA, Anderson RV, Siegman MG (1993) Low-flow cardiopulmonary bypass and cerebral protection: a summary of investigations. Ann Thorac Surg 56:1490-1492. CrossRef Medline

Trifilieff P, Rives ML, Urizar E, Piskorowski RA, Vishwasrao HD, Castrillon J, Schmauss C, Slättman M, Gullberg M, Javitch JA (2011) Detection of antigen interactions ex vivo by proximity ligation assay: endogenous dopamine D2-adenosine A2A receptor complexes in the striatum. BioTechniques 51:111-118. CrossRef Medline

Villeneuve NF, Lau A, Zhang DD (2010) Regulation of the Nrf2-Keap1 antioxidant response by the ubiquitin proteasome system: an insight into cullin-ring ubiquitin ligases. Antioxid Redox Signal 13:1699-1712. CrossRef Medline

Wang R, Tu J, Zhang Q, Zhang X, Zhu Y, Ma W, Cheng C, Brann DW, Yang F (2013) Genistein attenuates ischemic oxidative damage and behavioral deficits via eNOS/Nrf2/HO-1 signaling. Hippocampus 23:634-647. CrossRef Medline 
Wender PA, Mitchell DJ, Pattabiraman K, Pelkey ET, Steinman L, Rothbard JB (2000) The design, synthesis, and evaluation of molecules that enable or enhance cellular uptake: peptoid molecular transporters. Proc Natl Acad Sci U S A 97:13003-13008. CrossRef Medline

Wolman RL, Nussmeier NA, Aggarwal A, Kanchuger MS, Roach GW, Newman MF, Mangano CM, Marschall KE, Ley C, Boisvert DM, Ozanne GM, Herskowitz A, Graham SH, Mangano DT (1999) Cerebral injury after cardiac surgery: identification of a group at extraordinary risk. Multicenter Study of Perioperative Ischemia Research Group (McSPI) and the Ischemia Research Education Foundation (IREF) Investigators. Stroke 30:514-522. CrossRef Medline

Xu L, Emery JF, Ouyang YB, Voloboueva LA, Giffard RG (2010) Astrocyte targeted overexpression of Hsp72 or SOD2 reduces neuronal vulnerability to forebrain ischemia. Glia 58:1042-1049. CrossRef Medline

Yin W, Cao G, Johnnides MJ, Signore AP, Luo Y, Hickey RW, Chen J (2006) TAT-mediated delivery of $\mathrm{Bcl}-\mathrm{xL}$ protein is neuroprotective against neonatal hypoxic-ischemic brain injury via inhibition of caspases and AIF. Neurobiol Dis 21:358-371. CrossRef Medline
Zhang F, Wang S, Zhang M, Weng Z, Li P, Gan Y, Zhang L, Cao G, Gao Y, Leak RK, Sporn MB, Chen J (2012) Pharmacological induction of heme oxygenase-1 by a triterpenoid protects neurons against ischemic injury. Stroke 43:1390-1397. CrossRef Medline

Zhang QG, Han D, Wang RM, Dong Y, Yang F, Vadlamudi RK, Brann DW (2011) C terminus of Hsc70-interacting protein (CHIP)-mediated degradation of hippocampal estrogen receptor-alpha and the critical period hypothesis of estrogen neuroprotection. Proc Natl Acad Sci U S A 108: E617-E624. CrossRef Medline

Zhang QG, Wang RM, Scott E, Han D, Dong Y, Tu JY, Yang F, Reddy Sareddy G, Vadlamudi RK, Brann DW (2013) Hypersensitivity of the hippocampal CA3 region to stress-induced neurodegeneration and amyloidogenesis in a rat model of surgical menopause. Brain 136:1432-1445. CrossRef Medline

Zhao J, Redell JB, Moore AN, Dash PK (2011) A novel strategy to activate cytoprotective genes in the injured brain. Biochem Biophys Res Commun 407:501-506. CrossRef Medline 